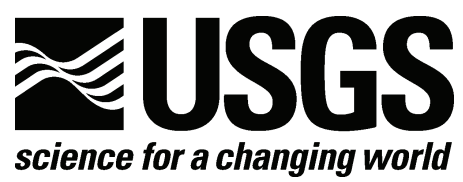

\title{
Biostratigraphic and lithologic correlations of two Sonoma County Water Agency pilot wells with the type Wilson Grove Formation, Sonoma County, central California
}

By Charles L. Powell, II' Robert J. McLaughlin' and Elmira Wan'

2006

U.S. Geological Survey Open-File Report 2006-1196

U.S. Department of the Interior

U.S. Geological Survey 


\section{U.S. Department of the Interior DIRK KEMPTHORNE, SECRETARY}

\section{U.S. Geological Survey P. Patrick Leahy, Acting Director}

\section{U.S. Geological Survey, Menlo Park, California 2006}

For product and ordering information:

World Wide Web: http://www.usgs.gov/pubprod

Telephone: 1-888-ASK-USGS

For more information on the USGS - the Federal source for science about the Earth, its natural and living resources, natural hazards, and the environment:

World Wide Web: http://www.usgs.gov

Telephone: 1-888-ASK-USGS

Suggested citation:

Powell, C.L., II, McLaughlin, R.J. and Wan, Elmira, 2006, Biostratigraphic and lithologic correlations of two Sonoma County Water Agency Pilot Wells with the type Wilson Grove Formation, Sonoma County, central California. U.S. Geological Survey Open-File Report 2006-1196, p. 37 p. [available on the World Wide Web at URL http://pubs.usgs.gov/of/2006/1196/ ].

Any use of trade, product, or firm names is for descriptive purposes only and does not imply endorsement by the U.S. Government.

Although this report is in the public domain, permission must be secured from the individual copyright owners to reproduce any copyrighted material contained within this report. 


\section{Contents}

Abstract

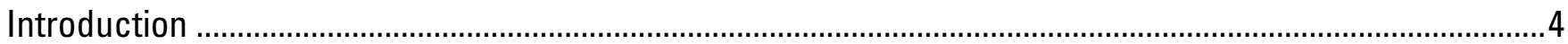

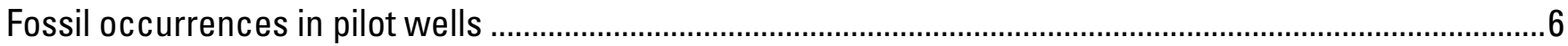

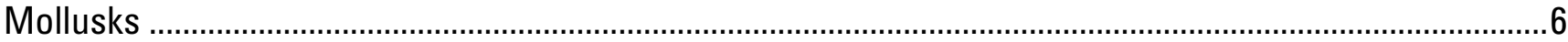

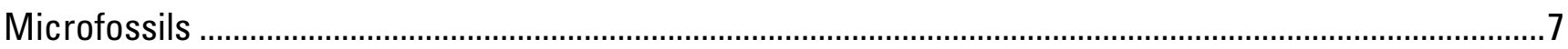

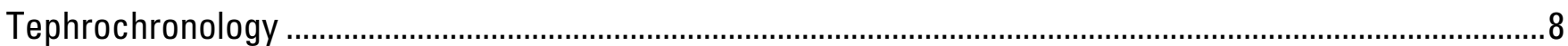

Well stratigraphy and regional stratigraphic relationships .........................................................................

Late Pliocene and Quaternary non-marine deposits .................................................................................

Late Miocene and Pliocene marine and non-marine deposits ...............................................................

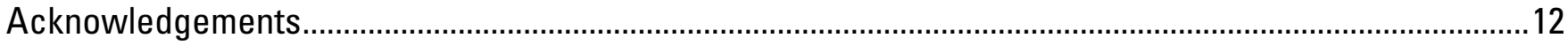

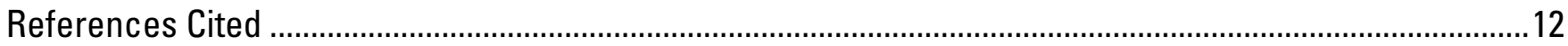

\section{Figures}

1. Index map showing the location of the Wilson Grove Formation (type locality), River Road at Trenton fossil locality, Sonoma County Water Agency Occidental Road and Sebastopol Road pilot wells, Sonoma County, central California

2. Benthic foraminifer Nonionella basispinata (Cushman and Moyer) recovered from between 380$390 \mathrm{ft}(116-119 \mathrm{~m})$ core interval in the Occidental Road pilot well

3. Diagram showing correlations between Sonoma County Water Agency Occidental Road and Sebastopol Road pilot wells, Sonoma County, central California based on mollusks (red) and lithology (blue).

\section{Tables}

1. Faunal list of mollusks identified at Order level or below, in the Sonoma County Water Agency Occidental Road pilot well, Sonoma County, central California.

\section{Appendix}

1. Macrofossil list from Sonoma County Water Agency Occidental Road and Sebastopol Road pilot wells, Sonoma County, central California

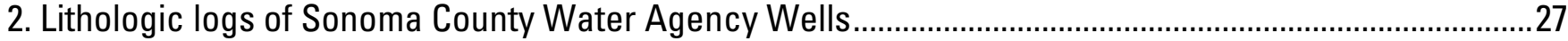

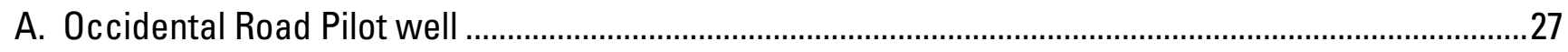

B. Sebastopol Road Pilot well. 


\title{
Biostratigraphic and lithologic correlations of two Sonoma County Water Agency pilot wells with the type Wilson Grove Formation, Sonoma County, central California
}

\author{
By Charles L. Powell, II' Robert J. McLaughlin' and Elmira Wan'
}

\begin{abstract}
Small mollusk faunas characteristic of the uppermost part of the Wilson Grove Formation at Wilson Grove and along River Road at Trenton (Pliocene) were encountered in Sonoma County Water Agency pilot wells at Occidental Road well field between 320-500 ft (98-152 m), depth, and in the Sebastopol Road pilot well field between 560-570 ft (171-174 m), depth. These mollusks support correlations between the two wells made on lithologic grounds.

A benthic foraminifer was recovered from between 380-390 ft (116-119 m), depth, in the Sonoma County Water Agency Occidental Road pilot well. Though an isolated specimen, the presence of this well-preserved foraminifer supports the environmental interpretation of less than $100 \mathrm{~m}$ on the continental shelf indicated by the molluscan assemblages at this site.

For this marine stratigraphic interval of the Wilson Grove Formation, we suggest a relatively narrow age range of 5.3 (Miocene-Pliocene boundary) to $\sim 4.5 \mathrm{Ma}$ based on the stratigraphic relations of correlative marine strata around the upland margin of Santa Rosa plain and correlative strata in the Santa Cruz area, although an age between 5.3 and $~ 2.8$ Ma cannot be discounted.
\end{abstract}

\section{Introduction}

The Occidental Road and Sebastopol Road pilot well sites are situated along the west side of the Santa Rosa plain which overlies the moderately deep $(\sim 2.5 \mathrm{~km})$ Cotati sedimentary basin filled with Miocene to Quaternary marine, estuarine and fluvial-lacustrine deposits (Figure 1). These strata are, in turn, intercalated with the Tolay Volcanics ( 10.6 to 8.5 Ma; Wagner and others, 2005) and the Sonoma Volcanics ( 8.5 to 2.5 Ma; Wagner and others, 2005). A system of Pliocene and younger normal faults bound the Santa Rosa plain on the southwest, and in the subsurface, the plain is partitioned by west-northwest-trending thrust faults, into the Cotati basin (to the south) and Windsor basin (to the north - not figured). The Cotati basin is bounded on the northeast by the active northwest-trending Rodgers Creek-Healdsburg fault zone. Detailed stratigraphy in these buried basins is important to our understanding of local groundwater supplies and the structural configuration of the basins has important earthquake hazards implications (McPhee and others, 2005). The complexity in stratigraphic and structural relations across faults bounding the Santa Rosa plain make it difficult to tie the geology of the surrounding uplands directly to the basin stratigraphy. However, previous work on the exposed basin margin

\footnotetext{
${ }^{1}$ U.S. Geological Survey, 345 Middlefield Road, Menlo Park, CA 94025
} 


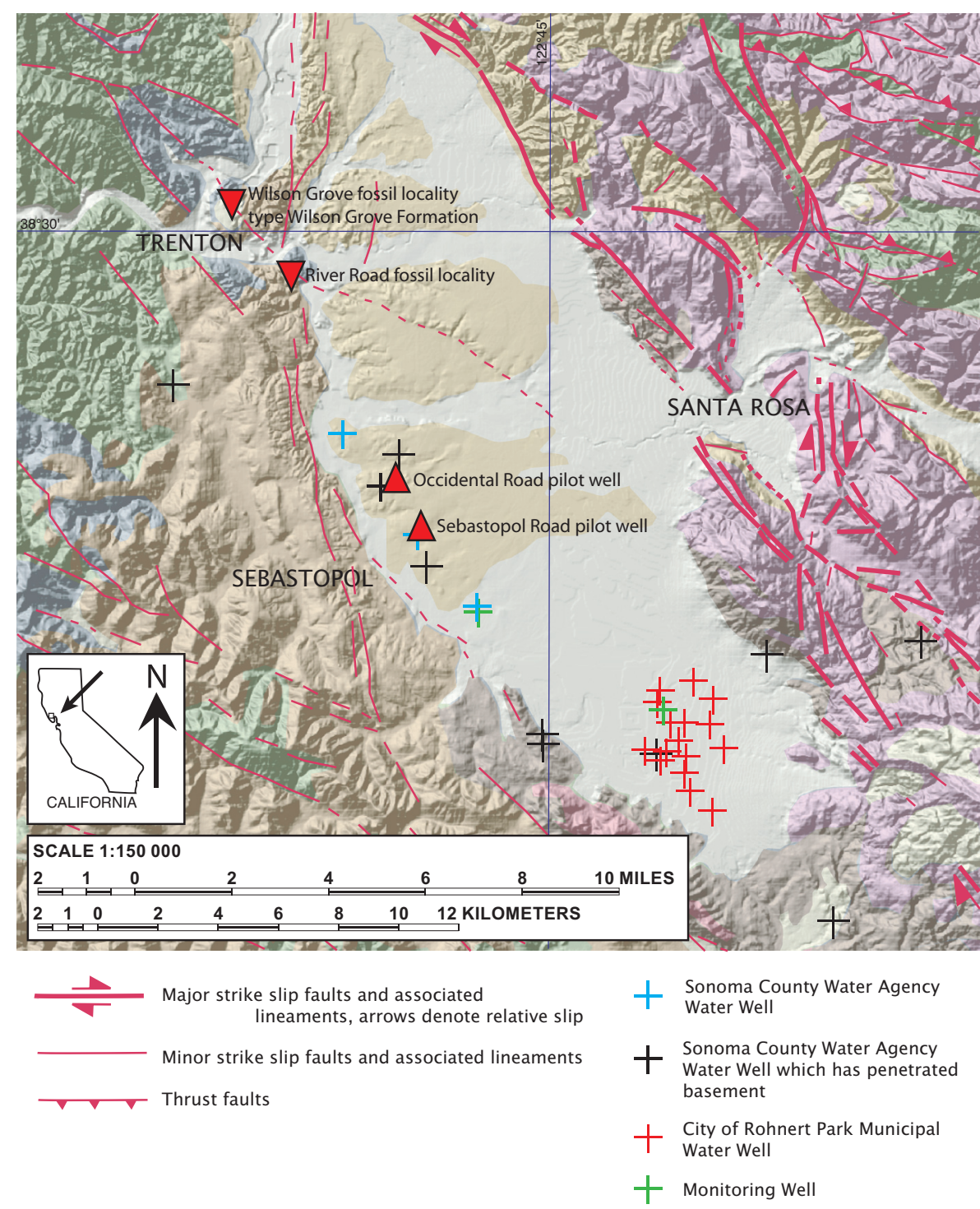

\section{DESCRIPTION OF MAP UNITS}

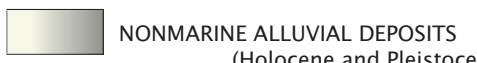
(Holocene and Pleistocene)-

FLUVIAL AND LACUSTRINE DEPOSITS (Pleistocene and Pliocene)-Largely overlies 2.78-2.5 m.y. old Sonoma interfingers with Sonoma Volcanics. Locally includes gravels that underlie 3.4 my. old ash flows. Commonly contains obsidian pebbles. SONOMA VOLCANICS (Late Pliocene-
Late Miocene 2.5-7.0MA)-Andesitic
to rhyodacitic flows, breccias and
tuffs. Volcanics young toward NE across strike-slip faults and interfinger with Pliocene to Miocene nonmarine to marine deposits Wilson Grove and Petaluma ocene gravels
WILSON GROVE FORMATION (Late Pliocene?-late Miocene)-Marine deposits, littoral to shelf setting, Roblar tuff of Sonoma Volcanics

PETALUMA FORMATION (Pliocenemiddle Miocene 6-10MA) - Fluvial, lacustrine and estuarine deposits that interfinger with lower Sonoma and Tolay Volcanics. Locally interfingers Sonoma Volcanics in upper part.

TOLAY VOLCANICS (late and middle Miocene $~ 8-10 \mathrm{MA}$ )-Andesite to dacite

COAST RANGE OPHIOLITE AND GREAT VALLEY SEQUENCE (Cretaceous

FRANCISCAN COMPLEX (Eocene-Late Jurassic)-Includes rocks of Central belt and Coastal belt-

Figure 1. Geologic map of the of the Cotati Basin part of the Santa Rosa plain area showing the location of surface outcrops of the Wilson Grove Formation (upside down triangles) at its type section at Wilson Grove and along River Road at Trenton and of Sonoma County Water Agency Occidental Road and Sebastopol Road pilot wells (triangles), Sonoma County, central California. 
stratigraphy (Fox, 1983; Allen, 2003) work on the stratigraphy in oil and gas wells (Wright and Smith, 1992; Zieglar, Wright, and Smith, 2005), and the compilation of water well data by Cardwell (1958) has provided a modern context (i.e. Valin and McLaughlin, 2005) for detailed biostratigraphic and chronostratigraphic analysis of the subsurface of Santa Rosa plain.

This report expands the above framework by documenting, for the first time, an invertebrate fauna in the subsurface of Santa Rosa plain that allows correlation to a paleontologically wellstudied Pliocene section along the western margin of Santa Rosa plain and to other correlative Pliocene sections elsewhere in central California. Based on the stratigraphic relations of correlative marine strata around the upland margin of Santa Rosa plain and the chronostratigraphic relations of correlative strata in the Santa Cruz area, an age younger than 5.3 Ma is indicated for the fossiliferous horizons in the pilot wells. Although some of the presently available stratigraphic evidence also permits an age as young as late Pliocene for the upper part of the fossiliferous section (Powell, Allen and Holland, 2004), other stratigraphic relations around the margins of the Santa Rosa Plain outlined here, suggest that the marine mollusk-bearing strata could have been deposited over a narrower time interval between 5.3 and 4.5 Ma. In addition, this correlation, furthermore, identifies a stratigraphic interval in the subsurface that will be useful in constraining displacements and deformation rates across basin bounding faults and on intra-basin fault partitions.

\section{Fossil occurrences in pilot wells}

Washed ditch samples from the two pilot wells have produced residues containing mollusks, mollusk fragments, and a microfossil. The Sonoma County Water Agency Occidental Road pilot well is located at $38.4229^{\circ} \mathrm{N}, 122.8088^{\circ} \mathrm{W}$ (NAD27), on the north side of Occidental Road about $1.7 \mathrm{~km}$ northwest of Llano, Sebastopol 7.5' quadrangle (Figure 1). This well contains fossiliferous samples in two shell beds that appear to be continuous, or nearly continuous. One shell bed is located between 320-690 ft (97-210 m) and the other is between 800-840 ft (244- 256 $\mathrm{m})$, total drilled depth.

The Sonoma County Water Agency Sebastopol Road pilot well is located at $38.4085^{\circ} \mathrm{N}$, $122.7995^{\circ} \mathrm{W}$ (NAD27), along the Petaluma and Santa Rosa railroad line about midway between Llano and the Sebastopol Grange (north of Gravenstein), Sebastopol 7.5' quadrangle (Figure 1). This well contains several shell beds based on continuous, or nearly continuous, fossil occurrences between 470-600 ft (143-183 m), 620-640 ft (189-195 m), 780-910 ft (238-277 m), 940-950 ft (287-290 m), and 1000-1070 ft (305-326 m).

Molluscan taxa identifiable at order level or below are present in the Occidental Road pilot well between 320-330 ft (98-101 m), 340-360 ft (104-110 m), 370-380 ft (113-116 m), 390-440 ft (119-134 m), 460-480 ft (140-146 m), and 500-510 ft (152-155 m) (Appendix 1). Identifiable taxa are present in the Sebastopol Road pilot well between 510-520 ft (155-158 m) and 560-570 ft (171$174 \mathrm{~m}$ ) (Appendix 1).

The microfossil taxon is identifiable to the species level and the specimen was recovered from the 380-390 ft (116-119 m) interval in the Occidental Road pilot well.

\section{Mollusks}

In the Occidental Road pilot well, the 320-500 ft (98-152 m) cutting depth interval contains a fauna similar to that found in the type Wilson Grove Formation at Wilson Grove, and along River Road at Trenton, both localities in northern Sonoma County (Figure 1). The small fauna reported here consists of eight identifiable taxa (one bivalve, seven gastropods; see Table 1). This fauna is too small for detailed age and environmental assessment. However, the occurrence of specimens questionably attributed to Nassarius grammatus (Dall) and Ophiodermella graciosana Arnold 
indicate a Pliocene age. Nassarius grammatus (Dall) has been reported in Pliocene formations from Humboldt County, northern California, to San Diego and possibly Baja California Norte, Mexico (Addicott, 1965). Ophiodermella graciosana (Arnold) occurs in the Careaga Sandstone in northern Santa Barbara County (Woodring and Bramlette, 1950), the Merced Formation (Yancey, 1978) on the San Francisco Peninsula, and the Purisima Formation (references in Powell, 1998) between Año Nuevo, San Mateo County and the Sargent oil field area in southern Santa Cruz County. All outcrops containing Ophiodermella graciosana Arnold are considered Pliocene. Moreover, environmentally, all of the taxa are marine and modern representatives of these genera mainly represent shelf water depths $(\leq 100 \mathrm{~m})$.

The Sebastopol Road pilot well contains only two specifically identified taxa, Nassarius sp., cf. N. grammatus (Dall) and Ophiodermella graciosana Arnold(?) both found between 560-570 ft (171-174 m). Other collections from this well contained only unidentifiable mollusk, bivalve, and gastropod fragments. The two species recovered from between 560-570 ft (171-174 m) are both present from the type Wilson Grove Formation at Wilson Grove and along River Road (Trenton), both in northern Sonoma County (Figure 1). Other occurrences are discussed above, but both species are restricted to the Pliocene. There is again too few taxa in the cuttings from this well for detailed age or environmental assessment. But, both taxa are restricted to the Pliocene and are marine forms with modern representatives of the genera most often encountered at shelf water depths ( 100 m or less).

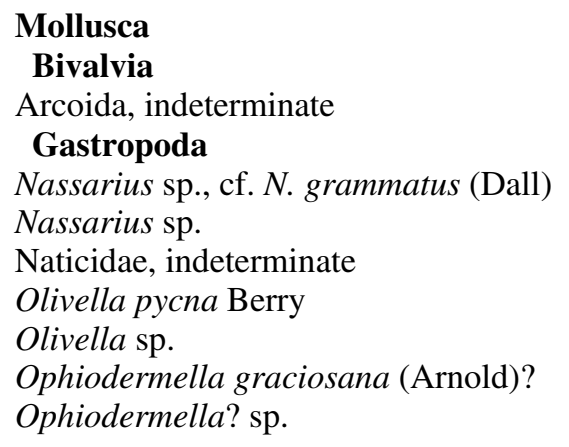

Table 1. Faunal list of mollusks identified at Order level or below, in the Sonoma County Water Agency Occidental Road pilot well, Sonoma County, central California.

Samples between 320-690 ft (98-210 m), depth in the Occidental Road pilot well and between 560-570 ft (171-174 m), depth (and likely above) in the Sebastopol Road pilot well contain the same species. These species are common in the type Wilson Grove and the River Road at Trenton fossil localities of the Wilson Grove Formation in northern Sonoma County (Powell, Allen and Holland, 2004) where these and associated species indicate a Pliocene age. The Pliocene age is supported by a biocorrelation of the River Road (Trenton) locality with the Pliocene part of the Purisima Formation section in the sea-cliffs at and south of Capitola in Santa Cruz County, central California (Powell, Allen, and Holland, 2004).

\section{Microfossils}

Samples were examined for microfossils while logging the Occidental Road and Sebastopol Road pilot wells. Elsewhere in this region, in cores from oil and gas wells in the Petaluma basin, and in surface exposures surrounding the Santa Rosa plain and Petaluma basin, fresh to brackish 
water diatoms and ostracodes and rare benthic foraminifers are preserved in fluvial, lacustrine and estuarine lithofacies of the Petaluma Formation (Starratt and others, 2005). Only a single benthic foraminifer was encountered during the course of this study.

A well-preserved benthic foraminifer, Nonionella basispinata (Cushman and Moyer)

(Figure 2), was recovered from between 380-390 ft (116-119 m) core interval in the Occidental

Road pilot well. $N$. basispinata is a long-ranging (Tertiary) taxon typically observed as a dominant species in inner shelf $(0-50 \mathrm{~m})$ benthic foraminiferal assemblages. However, it has been found in deeper, generally nutrient-rich, middle shelf (50-90 m) water depths off of San Francisco (Bandy, 1953, Quinterno and Gardner, 1987, McGann, personal communication). Off southern California, N. basispinata is characteristic of outer shelf (50-200 m) assemblages (Douglas and Heitman , 1979, K. McDougall, 2006, personal communication). Though an isolated specimen, the presence of $N$. basispinata supports the marine environmental interpretation indicated by the molluscan assemblage in this well.
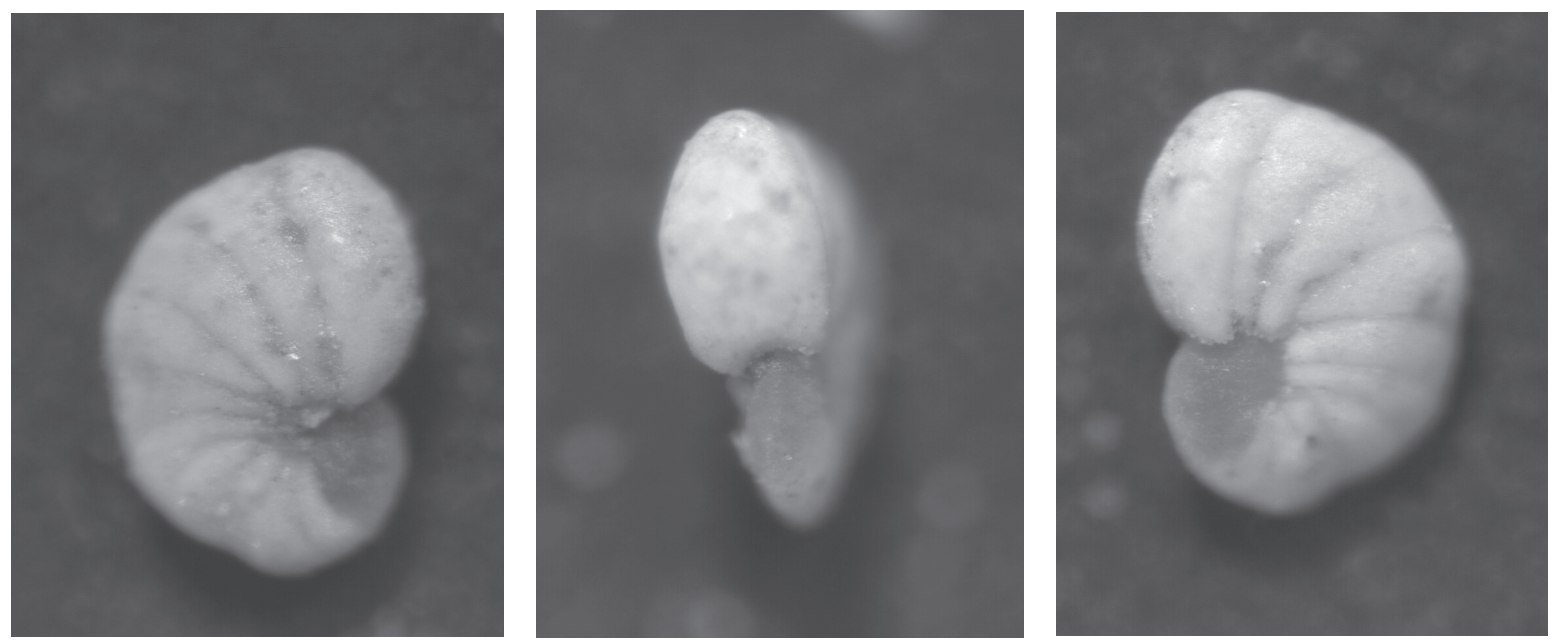

Figure 2. Nonionella basispinata (Cushman and Moyer). Digital photomicrograph of benthic foraminiferal specimen from Sonoma County Water Agency Occidental Road pilot well, Sonoma County, California, 380-390 feet, depth. Left: ventral view, center: profile, right: dorsal view. Magnification 160X.

\section{Tephrochronology}

Tephra or volcanic ash layers can be extremely useful for dating sedimentary sequences. Tephrochronology includes the use of established geochemical "fingerprinting" (usually by Electron Microprobe) and correlation techniques to identify and indirectly date sediment intervals containing isotropic glass shards from known volcanic eruptions or source areas (Sarna-Wojcicki, 1976; 1979).

The search for tephra-containing sediment layers from the Sonoma County pilot wells yielded largely negative results. Although some of the clay-rich horizons probably included finegrained tephra, inspection with binocular and petrographic microscopes failed to identify any recoverable unaltered glass shards. All of the examined intervals showed only quartz, feldspar, lithic grains, and altered or clayey composite grains that may have been vitreous or glassy prior to devitrification. In several stratigraphic intervals, very fine, globule-like grains resembling minute obsidian clasts were noted in the lithologic log (Appendix 2). Upon detailed examination, most of 
these grains turned out to be very fine sand-sized, rounded, and polished particles of chromite, ilmenite, chert or cherty argillite.

\section{Well stratigraphy and regional stratigraphic relationships}

Detailed lithologic descriptions of the washed cuttings from the Occidental Road and Sebastopol Road pilot wells (Appendix 2; summary - Figure 3) indicate the southwestern side of Santa Rosa plain southwest of Santa Rosa is underlain by 50-150 ft (15-46 m) of Pleistocene and Holocene floodplain and basin deposits. In turn, the deposits are underlain by $250-300 \mathrm{ft}$ (76-90 m) of Pliocene and Pleistocene fluvial to deltaic silt, sand, and gravel. Moreover, these sediments are underlain by at least 650 feet of dominantly shoreline to shelfal marine strata with minor nonmarine intercalations. These marine strata correlate with parts of the Petaluma and Wilson Grove Formations, which overlap in age and interfinger, transitioning from southeast to northwest, from a fluvial-lacustrine to a deltaic-estuarine, then to a marine littoral, and finally, to a shelfal depositional system (Allen, 2003; Powell, Allen, and Holland, 2004; Staratt and others, 2005). In addition, textural and sorting characteristics of the sediments suggest that one or more shoreline fluctuations are preserved in the lithologic records of these wells. Here we describe and stratigraphically correlate between the Occidental Road and Sebastopol Road pilot wells and to outcrops of the Wilson Grove Formation on the southwest side of Santa Rosa plain. These correlations are based on sedimentologic interpretation of textural and sorting characteristics of the cuttings in the wells, together with the paleontologic data and age constraints implied by stratigraphic and sedimentologic relations of the exposed surface deposits.

\section{Late Pliocene and Quaternary non-marine deposits}

The upper $\sim 50$ feet of the Occidental Road drill hole and the upper $\sim 150$ feet of the Sebastopol Road drill hole consist of Pleistocene and Holocene clayey to pebbly, dominantly lacustrine and non-marine basinal or distal floodplain deposits. These sediments are underlain in both wells, probably unconformably, by 265' (Occidental Road) and 300'(Sebastopol Road), respectively, of silt, sand and gravel, interpreted on the basis of textural and sorting characteristics, as distal fluvial, lacustrine, deltaic, and dune deposits. These deposits correspond at the surface to mildly to moderately tilted and locally folded fluvial and lacustrine sediments of late Pliocene and Pleistocene age, derived from several different local paleodrainage basins. These deposits include the Glen Ellen Formation, the Huichica Formation, and several other locally named and unnamed gravels.

\section{Pliocene marine and non-marine deposits}

Unconformably beneath the late Pliocene and Pleistocene non-marine section in the Occidental Road and Sebastopol Road wells are strata assigned here to the Petaluma and Wilson Grove Formations. The dominantly marine character of these strata and the shelfal affinities of the mollusks lead us to assign most of the beds to the Wilson Grove Formation. Some poorly sorted pebbly strata in the section, which are devoid of fossil or bioclastic debris, could represent minor fluvial or estuarine intertongues of the Petaluma Formation in the dominantly marine shelfal and littoral section. Most of the pebbly to gravelly component of this section is characterized by wellrounded and polished clasts and locally the gravels are clast supported and nearly devoid of fines. These deposits are interpreted here to be indicative of well-winnowed (washed) shoreline deposits (i.e., intertidal depositional setting). 
SF-98003-Occidental Road Pilot Well

SF-98003-Sebastopol Road Pilot Well

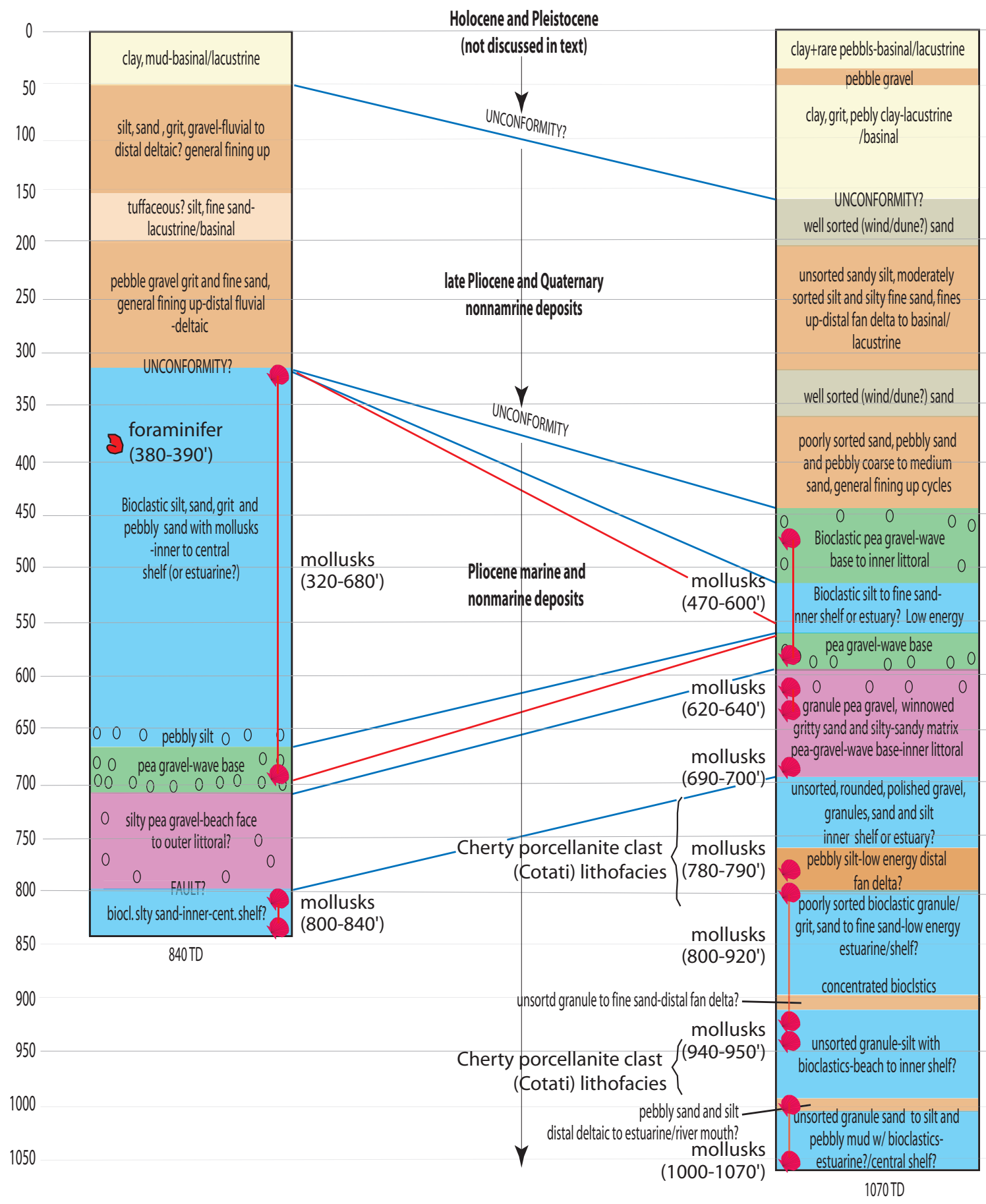

1100

Figure 3. Correlations between Sonoma County Water Agency Occidental Road and Sebastopol Road pilot wells, Sonoma County, central California, based on mollusks (red) and lithology (blue). Also shows stratigraphic occurrence of fossils and the cherty porcellaneous clast (Monterey-like pebble lithofacies) deposits. 
A distinctive lithofacies of these marine deposits, noted in the Sebastopol Road pilot well, is characterized by banded porcellanite pebbles. This lithofacies resembles a cherty porcellaneous lithofacies common in middle Miocene part of the Monterey Formation and the equivalent Claremont Shale of the Monterey Group of the eastern San Francisco Bay region (Allen, 2003; Allen and Repenning, 2005). In addition, this lithofacies is a common component of the gravels in the sand and gravel of Cotati (Fox, 1983), exposed at the surface on the southwest side of the Santa Rosa plain near Cotati, as a lithofacies of the Petaluma Formation. In the Sebastopol Road pilot well Monterey-like porcellanite pebbles, some of which appear to contain foraminifers, occur within two depth intervals, between $720-810 \mathrm{ft}$ and 940-990 ft. No pebbles of this lithology were noted in the Occidental Road well, which was drilled to a total depth of only $840 \mathrm{ft}$. On the basis of the mollusks and lithologic correlations, it appears that the Occidental Road pilot well did not reach the depth of the sand and gravel of Cotati of the Petaluma Formation, providing another important lithologic constraint to our correlation to the Wilson Grove Formation type section.

Fossil occurrences and stratigraphic relations at the River Road at Trenton and Wilson Grove fossil localities of the Wilson Grove Formation permit an age range for these strata of between 5.3 Ma to $\geq 2.8 \mathrm{Ma}$, based on the extinct (Pliocene) mollusks discussed above and age constraints of an unconformity between the Wilson Grove Formation and an overlying unit of fluvial gravel containing obsidian from a Napa Valley source (McLaughlin and others, 2005). Other regional stratigraphic relations could indicate that sections of Wilson Grove Formation along River Road at Trenton and at Wilson Grove could be significantly older than $2.8 \mathrm{Ma}$, and are confined to a relatively shorter depositional window between 5.3 to 4.5 Ma.

The Wilson Grove Formation is overlain unconformably by late Pliocene and(or) Pleistocene fluvial sediments that have been assigned by others to the Glen Ellen Formation (Fox, 1983; Fox and others, 1985) east of Wilson Grove. The Glen Ellen Formation in this area locally includes gravels with minor but conspicuous obsidian pebbles that have been geochemically fingerprinted and correlated to a radiometrically dated source material from the Sonoma Volcanics in the Napa Valley (Napa-Glass Mountain obsidian source area) (McLaughlin and others, 2005). The Napa Valley obsidian source has an ${ }^{40} \mathrm{Ar} /{ }^{39} \mathrm{Ar}$ age of $2.8 \mathrm{Ma}$ (McLaughlin and others, 2005). This implies that the Glen Ellen Formation overlying the Wilson Grove Formation is younger than $2.8 \mathrm{Ma}$. Although we assume they are coeval with obsidian-bearing gravels northeast of the Trenton and Wilson Grove localities, non-marine fluvial and lacustrine sediments that overlie Wilson Grove equivalent strata in the Occidental Road and Sebastopol Road Pilot wells lack obsidian pebbles. The lack of obsidian detritus in Pliocene and Pleistocene strata south of Trenton may be related to structural partitioning of the subsurface of Santa Rosa plain into two separate basins by the Trenton thrust fault, but the lack of obsidian cannot be resolved here.

Other fluvial gravels that crop out east of the River Road at Trenton and Wilson Grove fossil localities along the east side of Santa Rosa plain near Santa Rosa, unconformably overlie Petaluma Formation strata containing a Monterey-like pebble lithofacies. The Monterey-like pebble lithofacies is similar to one seen in the lower part of the Sebastopol Road pilot well section. The gravels overlying the Petaluma Formation in this area include obsidian pebbles. However, the source of the obsidian pebbles, based on their geochemical signature (McLaughlin and others, 2005), is directly east of Santa Rosa at Annadel State Park. The obsidian source at Annadel State Park is dated by ${ }^{40} \mathrm{Ar} /{ }^{39} \mathrm{Ar}$ techniques at $\sim 4.5 \mathrm{Ma}$ (McLaughlin and others, 2005). The stratigraphic position of these gravels unconformably above the Monterey-like pebble lithofacies of the Petaluma Formation, indicates that the overlying gravel is $\leq 4.5 \mathrm{Ma}$ but possibly could be much younger than the age of the obsidian clast source. The Annadel-sourced gravel appears to be underlain by andesitic volcanic rocks and the $4.8 \mathrm{Ma}$ Lawlor Tuff that are intercalated with or overlie the Petaluma Formation in this area. Although exposures are complicated by faulting, this 
relation suggests that the Monterey-like pebble lithofacies of the Petaluma Formation could be $\geq$ 4.8 Ma in age.

The notable lack of any obsidian clasts in the Wilson Grove Formation on the west side of Santa Rosa plain and in the pilot well drill holes, could be interpreted to indicate that the Wilson Grove strata at River Road at Trenton, at Wilson Grove, and in the Occidental Road and Sebastopol Road pilot wells are: 1) entirely older than the $2.8 \mathrm{Ma}$ and 4.5 Ma obsidian clast sources for the late Pliocene and Pleistocene gravels overlying the Petaluma and Wilson Grove Formations; 2) that neither of the obsidian clast sources were exposed to erosion until after deposition of the Wilson Grove Formation late in the Pliocene and early Pleistocene; or 3) that depositional systems carrying sediment sourced in the Napa-Franz Valley and Annadel areas never reached the southwestern Santa Rosa plain. Alternative 1) implies that the Wilson Grove Formation is entirely older than 4.5 $\mathrm{Ma}$ and a significant unconformity between $\sim 4.5$ and $\sim 2.8 \mathrm{Ma}$. Alternative 2) permits relatively uninterrupted Wilson Grove Formation deposition well into the late Pliocene, with major uplift and unroofing of depositional sources in the Sonoma Volcanics after $2.8 \mathrm{Ma}$. Alternative 3 explains the lack of obsidian clasts in the Wilson Grove Formation merely by a limit in the westward reaches of the fluvial systems carrying obsidian detritus from their source regions. It is noted, however, that Napa-Franz Valley obsidian pebbles are present in Pliocene and Pleistocene gravels that overlie marine Wilson Grove strata immediately east of Wilson Grove in the Windsor basin, which argues against alternative 3 . None of these alternative interpretations uniquely explain the stratigraphic relations presented herein, although alternative 1) is favored as a better fit to the available data and field relations.

The lower part of the River Road section of the Wilson Grove Formation at Trenton includes the 6.3 Ma Roblar tuff of Sarna-Wojcicki (1992) (Sarna-Wojcicki, 1992; McLaughlin and others, 2005). The Roblar tuff of Sarna-Wojcicki (1992) is also present along the east side of the Santa Rosa plain, stratigraphically beneath local Monterey-like pebble lithofacies gravels. The fossiliferous sections described from River Road at Trenton and Wilson Grove are stratigraphically above the Roblar tuff (Allen, 2005; Powell, Allen, and Holland, 2004), consistent with the age based on fossils. The Roblar tuff of Sarna-Wojcicki (1992) is absent in the Occidental Road and Sebastopol Road pilot wells. The well stratigraphy suggests that the tuff is probably present below the drilled depths of the wells.

\section{Acknowledgments}

We thank Chris Farrar, Scott Starratt, and Don Sweetkind (all USGS) for their careful reviews of the manuscript and Mary McGann (USGS) for providing the foraminifer photographs. We also thank the Sonoma County water agency for access to the samples.

\section{References Cited}

Addicott, W.O., 1965, Some western American Cenozoic gastropods of the genus Nassarius: U.S. Geological Survey Professional Paper 503B, p. B1-B24.

Allen, J.R., 2003, Stratigraphy and tectonics of Neogene strata, northern San Francisco Bay area: San Jose, Calif. San Jose State University, M.S. thesis, p. 1-188.

Allen, J.R., and Repenning, C.A., 2005, Lithology and vertebrate fossils of the Petaluma Formation, Sonoma County, California: Geological Society of America Abstracts with Programs, v. 37, no.4, p. 70 . 
Bandy, O.L., 1953, Ecology and paleoecology of some California foraminifera, Part I. The frequency distribution of recent foraminifera of California: Journal of Paleontology, v. 27, p. 161-203.

Cardwell, G.T., 1958, Geology and ground water in the Santa Rosa and Petaluma Valley areas, Sonoma County, California: U.S. Geological Survey Water-supply Paper 1427, p. 1-273.

Douglas, R.G. and Heitman, H.L., 1979, Slope and basin benthic foraminifera of the California Borderland: Society of Economic Paleontologists and Mineralogists Special Publication 27, p. 231-256.

Fox, K.F., Jr., 1983, Tectonic setting of late Miocene, Pliocene, and Pleistocene rocks in part of the Coast Ranges north of San Francisco, California: U.S. Geological Survey Professional Paper 1239, p. 1-33.

Fox, K.F., Jr., Fleck, R.J., Curtis, G.H., Garniss, H., and Meyers, C.E., 1985, Implications of the northwestwardly younger age of the volcanic rocks of west-central California: Geological Society of America Bulletin, v. 96, no. 5, p. 647-654.

Langenheim, V.E., Roberts, C.W., McCabe, C.A., McPhee, D.K., Tilden, J.E., and Jachens, R.C., 2006, Preliminary Isostatic Gravity Map of the Sonoma Volcanic Field and Vicinity, Sonoma and Napa Counties, California: U.S. Geological Survey Open-File Report 2006-1056, 1 sheet, scale 1:100,000. http://pubs.usgs.gov/of/2006/1056/.

McLaughlin, R.J., Wagner, D.L., Sweetkind, D.S., Sarna-Wojcicki, A.M., Rytuba, J.J., Langenheim, V.E., Fleck, R.J., Jachens, R.C., and Deino, A., 2005, Late Neogene transition from transform to subduction margin east of the San Andreas fault in the wine country of the northern San Francisco Bay Area, California: Fieldtrip 10, Guidebook and volume for the joint meeting of Cordilleran Section GSA and Pacific Section AAPG, Book 98, 112p.

McPhee, D.K., Langenheim, V.E., Jachens, R.C., McLaughlin, R.J., and Roberts, C.W., 2005, Basin structure beneath the Santa Rosa Plain, northern California, and its possible influence on damage patterns from the 1906 and 1969 earthquakes [abs.]: Geological Society of America Abstracts with Programs, v. 37, no. 4, p. 84.

Powell, C.L., II, 1998, The Purisima Formation and related rocks (upper Miocene-Pliocene), greater San Francisco Bay area, central California: review of literature and USGS collections (now housed at the Museum of Paleontology, University of California, Berkeley): U.S. Geological Survey Open-File Report 98-594, p. 1-102 http://pubs.usgs.gov/of/1998/of98-594/. Powell, C.L., II, Allen, J.R., and Holland, P.J., 2004, Invertebrate paleontology of the Wilson Grove Formation (late Miocene to late Pliocene), Sonoma and Marin Counties, California, with some observations on its stratigraphy, thickness, and structure: U.S. Geological Survey OpenFile Report 2004-1017, p. 1-106 http://pubs.usgs.gov/of/2004/1017/.

Quinterno, P.J., and Gardner, J.V., 1987, Benthic foraminifers on the continental shelf and upper slope, Russian River area, northern California: Journal of Foraminiferal Research, v. 17, no. 2, p. 132-152.

Sarna-Wojcicki, A.M., 1976, Correlation of late Cenozoic tuffs in the central Coast Ranges of California by means of trace-and minor-element chemistry. U.S. Geological Survey Professional Paper 972, $30 \mathrm{p}$.

Sarna-Wojcicki, A.M., 1979, Chemical correlation of some late Cenozoic tuffs of northern and central California by neutron activation analysis of glass and comparison with X-ray fluorescence. U.S. Geological Survey Professional Paper 1147, 15 p.

Sarna-Wojcicki, A.M., 1992, Long-term displacement rates of the San Andreas fault system in northern California from the 6-Ma Roblar tuff [abs.], in Borchardt, G., and others, eds., Proceedings of the second conference on earthquake hazards in the eastern San Francisco Bay 
area: California Department of Conservation, Division of Mines and Geology Special Publication 113, p. 29-30.

Starratt, S.W., Allen, J.R., Peterson, D., Powell, C.L. II, Ruck, E., and Sarna-Wojcicki, A.M., 2005, New paleontological evidence supporting the Neogene transition from marine to non-marine conditions in Marin and Sonoma counties, California, USA [abs.]. Geological Society of America, Abstracts with Programs, v. 37, no. 4, p. 69.

Valin, Z.C., and McLaughlin, R.J., 2005, Locations and data for water wells of the Santa Rosa Valley, Sonoma County, California: U.S. Geological Survey Open-File Report 2005-1318, p. 116, http://pubs.usgs.gov/of/2005/1318/.

Wagner, D.L., Fleck, R.J., McLaughlin, R.J., Sarna-Wojcicki, A.M., Clahan, K.B., and Bezore, S., 2005, New constraints on the age and distribution of Cenozoic volcanics north of San Pablo Bay, California: implications for displacement along faults inboard of the San Andreas fault [abs.]. Geological Society of America Abstracts with Programs, v. 37, no. 4, p. 83.

Woodring, W.P., and Bramlette, M.N., 1950, Geology and paleontology of the Santa Maria District, California. U.S. Geological Survey Professional Paper 222, 185 p.

Wright, T.L., and Smith, N., 1992, Right step from the Hayward Fault to the Rodgers Creek fault beneath San Pablo Bay, in Borchardt, G., and others, eds., Proceedings of the second conference on earthquake hazards in the eastern San Francisco Bay area: California Department of Conservation, Division of Mines and Geology Special Publication 113, p. 407-417.

Yancey, T.E., 1978, Stratigraphy of the Plio-Pleistocene strata in the Twelvemile Creek area, San Francisco Peninsula, California: Proceedings of the California Academy of Sciences, Fourth Series, v. 41, no. 5, p. 357-370.

Zieglar, D.L., Wright, T.L., and Smith, N., 2005, Subsurface geology in the northern San Francisco Bay region, California [abs.]: Geological Society of America Abstracts with Programs, v. 37, no. 4, p. 69. 


\section{Appendix 1: Macrofossil samples}

Forty-one washed ditch samples from Sonoma County Water Agency-Occidental Road Pilot Well were found to contain mollusk shells or fragments. The well is located at $38.4229^{\circ} \mathrm{N}$, $122.8088^{\circ} \mathrm{W}$ (NAD27), on the north side of Occidental Road about $1.7 \mathrm{~km}$ northwest of Llano, Sebastopol 7.5' Quadrangle, Sonoma County, California.

Field No.: 320'-330' (98-101 m).

Mollusca

Bivalvia

Indeterminate fragments

Gastropoda

Nassarius sp., cf. N. grammatus (Dall)

Olivella pycna Berry

Indeterminate fragments

Field No.: 330'-340' (101-104 m).

Mollusca

Bivalvia

Indeterminate fragments

Gastropoda

Indeterminate fragments

Field No.: 340'-350' (104-107 m).

Mollusca

Bivalvia

Indeterminate fragments

Gastropoda

Nassarius sp.

Indeterminate fragments

Field No.: 350'-360' (107-110 m).

Mollusca

Bivalvia

Indeterminate fragments

Gastropoda

Naticidae?, indeterminate

Indeterminate fragments

Field No.: 360'-370' (110-113 m).

Mollusca

Bivalvia

Indeterminate fragments 
Gastropoda

Indeterminate fragments

Field No.: 370'-380' (113-116 m).

Mollusca

Bivalvia

Indeterminate fragments

Gastropoda

Nassarius sp.

Indeterminate fragments

Field No.: 380'-390' (116-119 m).

Mollusca

Bivalvia

Indeterminate fragments

Gastropoda

Indeterminate fragments

Field No.: 390'-400' (119-122 m).

Mollusca

Bivalvia

Indeterminate fragments

Gastropoda

Olivella pycna Berry

Indeterminate fragments

Field No.: 400'-410' (122-125 m).

Mollusca

Bivalvia

Indeterminate fragments

Gastropoda

Olivella pycna Berry

Indeterminate fragments

Field No.: 410'-420' (125-128 m).

Mollusca

Bivalvia

Indeterminate fragments

Gastropoda

Nassarius? sp.

Olivella pycna Berry

Indeterminate fragments

Field No.: 420'-430' (128-131 m).

Mollusca 
Bivalvia

Indeterminate fragments

Gastropoda

Nassarius sp., cf. N. grammatus (Dall)

Olivella pycna Berry

Indeterminate fragments

Field No.: 430'-440' (131-134 m).

Mollusca

Bivalvia

Indeterminate fragments

Gastropoda

Nassarius sp., cf. N. grammatus (Dall)

Olivella pycna Berry

Ophiodermella graciosana Arnold(?)

Indeterminate fragments

Field No.: 440'-450' (134-137 m).

Mollusca

Bivalvia

Indeterminate fragments

Gastropoda

Indeterminate fragments

Field No.: 450'-460' (137-140 m).

Mollusca

Bivalvia

Indeterminate fragments

Gastropoda

Nassarius? sp.

Olivella sp.

Indeterminate fragments

Field No.: 460'-470' (140-143 m).

Mollusca

Bivalvia

Indeterminate fragments

Gastropoda

Nassarius? sp.

Olivella sp.

Indeterminate fragments

Field No.: 470'-480' (143-146 m).

Mollusca

Bivalvia 
Indeterminate fragments

Gastropoda

Nassarius? sp.

Olivella sp.

Ophiodermella? sp.

Indeterminate fragments

Field No.: 480'-490' (146-149 m).

Mollusca

Bivalvia

Indeterminate fragments

Gastropoda

Indeterminate fragments

Field No.: 490'-500' (149-152 m).

Mollusca

Bivalvia

Indeterminate fragments

Gastropoda

Indeterminate fragments

Field No.: 500'-510' (152-155 m).

Mollusca

Bivalvia

Indeterminate fragments

Gastropoda

Nassarius sp., cf. N. grammatus (Dall)

Indeterminate fragments

Field No.: 510'-520' (155-158 m).

Mollusca

Bivalvia

Indeterminate fragments

Gastropoda

Indeterminate fragments

Field No.: 520'-530' (158-161 m).

Mollusca

Bivalvia

Indeterminate fragments

Gastropoda

Indeterminate fragments

Field No.: 530'-540' (161-165 m).

Mollusca 
Bivalvia

Indeterminate fragments

Gastropoda

Indeterminate fragments

Field No.: 540'-550' (165-168 m).

Mollusca

Bivalvia

Indeterminate fragments

Gastropoda

Indeterminate fragments

Field No.: 550'-560' (168-171 m).

Mollusca

Bivalvia

Indeterminate fragments

Gastropoda

Indeterminate fragments

Field No.: 560'-570' (171-174 m).

Mollusca

Bivalvia

Indeterminate fragments

Gastropoda

Indeterminate fragments

Field No.: 570'-580' (174-177 m).

Mollusca

Bivalvia

Indeterminate fragments

Gastropoda

Indeterminate fragments

Field No.: 580'-590' (177-180 m).

Mollusca

Bivalvia

Arcoida, indeterminate (taxodont hinge fragment)

Indeterminate fragments

Gastropoda

Indeterminate fragments

Field No.: 590'-600' (180-183 m).

Mollusca

Bivalvia

Indeterminate fragments 
Gastropoda

Indeterminate fragments

Field No.: 600'-610' (183-186 m).

Mollusca

Bivalvia

Indeterminate fragments

Gastropoda

Indeterminate fragments

Field No.: 610'-620' (186-189 m).

Mollusca

Bivalvia

Indeterminate fragments

Gastropoda

Indeterminate fragments

Field No.: 620'-630' (189-192 m).

Mollusca

Bivalvia

Indeterminate fragments

Gastropoda

Indeterminate fragments

Field No.: 630'-640' (192-195 m).

Mollusca

Bivalvia

Indeterminate fragments

Gastropoda

Indeterminate fragments

Field No.: 640'-650' (195-198 m).

Mollusca

Indeterminate fragments

Field No.: 650'-660' (198-201 m).

Mollusca

Bivalvia

Indeterminate fragments

Field No.: 660'-670' (201-204 m).

Mollusca

Indeterminate fragments 
Field No.: 670'-680' (204-207 m).

Mollusca

Indeterminate fragments

Field No.: 680'-690' (207-210 m).

Mollusca

Indeterminate fragments

Field No.: 800'-810' (244-247 m).

Mollusca

Indeterminate fragments

Field No.: 810'-820' (247-250 m).

Mollusca

Indeterminate fragments

Field No.: 820'-830' (250-253 m).

Mollusca

Indeterminate fragments

Field No.: 830'-840' (253-256 m).

Mollusca

Indeterminate fragments

Thirty-five washed ditch samples from Sonoma County Water Agency- Sebastopol Road pilot well were found to contain mollusk shells or fragments. The well is located at $38.4085^{\circ} \mathrm{N}, 1^{22.7995^{\circ} \mathrm{W}}$ (NAD27), along the Petaluma and Santa Rosa railroad line about midway between Llano and the Sebastopol Grange (just north of Gravenstein), Sebastopol 7.5' Quadrangle, Sonoma County, California.

Field No.: 470'-480' (143-146 m).

Mollusca

Indeterminate fragments

Field No.: 480'-490' (146-149 m).

Mollusca

Bivalvia

Indeterminate fragments

Field No.: 490'-500' (149-152 m).

Mollusca

Bivalvia 
Indeterminate fragments

Field No.: 500'-510' (152-155 m).

Mollusca

Bivalvia

Indeterminate fragments

Field No.: 510'-520' (155-158 m).

Mollusca

Bivalvia

Indeterminate fragments

Gastropoda

Astyris? sp.

Indeterminate fragments

Field No.: 520'-530' (158-162 m).

Mollusca

Bivalvia

Indeterminate fragments

Gastropoda

Indeterminate fragments

Field No.: 530'-540' (162-165 m).

Mollusca

Bivalvia

Indeterminate fragments

Gastropoda

Indeterminate fragments

Field No.: 540'-550' (165-168 m).

Mollusca

Bivalvia

Indeterminate fragments

Gastropoda

Indeterminate fragments

Field No.: 550'-560' (168-171 m).

Mollusca

Bivalvia

Indeterminate fragments

Gastropoda

Indeterminate fragments 
Field No.: 560'-570' (171-174 m).

Mollusca

Bivalvia

Indeterminate fragments

Gastropoda

Nassarius sp., cf. N. grammatus (Dall)

Ophiodermella graciosana Arnold?

Indeterminate fragments

Field No.: 570'-580' (174-177 m).

Mollusca

Bivalvia

Indeterminate fragments

Gastropoda

Indeterminate fragments

Field No.: 580'-590' (177-180 m).

Mollusca

Bivalvia

Indeterminate fragments

Gastropoda

Indeterminate fragments

Field No.: 590'-600' (180-183 m).

Mollusca

Bivalvia

Indeterminate fragments

Gastropoda

Indeterminate fragments

Field No.: 620'-630' (189-192 m).

Mollusca

Bivalvia

Indeterminate fragments

Field No.: 630'-640' (192-195 m).

Mollusca

Bivalvia

Indeterminate fragments

Field No.: 690'-700' (210-213 m).

Mollusca

Bivalvia

Indeterminate fragments 
Field No.: 780'-790' (238-241 m).

Mollusca

Bivalvia

Indeterminate fragments

Field No.: 800'-810' (244-247 m).

Mollusca

Bivalvia

Indeterminate fragments

Vertebrata

Bone fragment(?)

Field No.: 810'-820' (247-250 m).

Mollusca

Bivalvia

Indeterminate fragments

Field No.: 820'-830' (250-253 m).

Mollusca

Bivalvia

Indeterminate fragments

Field No.: 830'-840' (253-256 m) .

Mollusca

Bivalvia

Indeterminate fragments

Field No.: 840'-850' (256-259 m)

Mollusca

Bivalvia

Indeterminate fragments

Field No.: 850'-860' (259-262 m).

Mollusca

Indeterminate fragments

Field No.: 860'-870' (262-265 m).

Mollusca

Indeterminate fragments

Field No.: 870'-880' (265-268 m).

Mollusca

Indeterminate fragments 
Field No.: 880'-890' (268-271 m).

Mollusca

Bivalvia

Indeterminate fragments

Field No.: 890'-910' (271-277 m).

Mollusca

Bivalvia

Indeterminate fragments

Field No.: 910'-920' (277-280 m).

Mollusca

Indeterminate fragments

Field No.: 940'-950' (287-290 m).

Mollusca

Bivalvia

Indeterminate fragments

Field No.: 1000'-1010' (305-308 m).

Mollusca

Bivalvia

Indeterminate fragments

Field No.: 1020'-1030' (311-314 m).

Mollusca

Bivalvia

Indeterminate fragments

Field No.: 1030'-1040' (314-317 m).

Mollusca

Bivalvia

Indeterminate fragments

Field No.: 1040'-1050' (317-320 m).

Mollusca

Bivalvia

Indeterminate fragments

Field No.: 1050'-1060' (320-323 m).

Mollusca

Bivalvia

Indeterminate fragments 
Field No.: 1060'-1070' (323-326 m).

Mollusca

Bivalvia

Indeterminate fragments 


\section{Appendix 2: Lithologic logs of ditch samples}

\section{Lithologic logs of washed ditch samples from Sonoma County Water Agency-Occidental Road Pilot Well located at $38.4229^{\circ} \mathrm{N}, 122.8088^{\circ} \mathrm{W}$ (NAD27), on the north side of Occidental Road about 1.7 km northwest of Llano, Sebastopol 7.5' Quadrangle, Sonoma County, California.}

\begin{tabular}{|c|c|c|}
\hline $\operatorname{Depth}(\mathbf{f t})$ & Lithology & Notes \\
\hline $20-30(6-9 \mathrm{~m})$ & Mudstone; clayey grey. & May be tuffaceous. \\
\hline $30-40(9-12 \mathrm{~m})$ & Mudstone; clayey dark grey. & May be tuffaceous. May have ostracodes or diatoms. \\
\hline $40-50(12-15 \mathrm{~m})$ & $\begin{array}{l}\text { Mudstone; clayey dark grey, with } \\
\text { angular white fragments to } 5 \mathrm{~mm} \text {. }\end{array}$ & May be tuffaceous. May have ostracodes or diatoms. \\
\hline $50-60(15-18 \mathrm{~m})$ & $\begin{array}{l}\text { Sandstone; silty-muddy, with white } \\
\text { tephra-like fragments, much fine } \\
\text { quartzo-feldspathic matrix, and Tertiary } \\
\text { volcanics, abundant } \\
\text { Franciscan/Mesozoic lithics. }\end{array}$ & Probably tuffaceous silt. \\
\hline $60-70(18-21 \mathrm{~m})$ & $\begin{array}{l}\text { Sand; quartzo-feldspathic with hard, } \\
\text { white, rhyolitic lithics and lithified } \\
\text { sandstone fragments. }\end{array}$ & Minor white tuff(?) fragments. \\
\hline $70-80(21-24 \mathrm{~m})$ & Sand; quartzo-feldspathic, lithic, gritty. & $\begin{array}{l}\text { Includes rounded to subrounded, black chert and } \\
\text { argillite (chalcedonic) pebbles + mostly Mesozoic- } \\
\text { derived lithics. }\end{array}$ \\
\hline $80-90(24-27 \mathrm{~m})$ & Grit; quartzo-feldspathic. & $\begin{array}{l}\text { Clasts include white rounded vein quartz, dark chert, } \\
\text { scattered ashy rhyolite, subrounded, hard meta- } \\
\text { sandstone. }\end{array}$ \\
\hline $\begin{array}{l}90-100(27-30 \\
\mathrm{m})\end{array}$ & Same as 80-90'. & $\begin{array}{l}\text { Includes a 1-cm diameter, subrounded, fine-grained, tuff } \\
\text { pebble. }\end{array}$ \\
\hline $\begin{array}{l}100-110(30-34 \\
\mathrm{m})\end{array}$ & $\begin{array}{l}\text { Sand; fine to medium grained, lithic } \\
\text { quartzo-feldspathic. }\end{array}$ & $\begin{array}{l}\text { Includes probable minor tephra component and fine to } \\
\text { medium-grained, rounded, black chert clasts. }\end{array}$ \\
\hline $\begin{array}{l}110-120(34-37 \\
m)\end{array}$ & $\begin{array}{l}\text { Sand; pebbly lithic, quartzo-feldspathic. } \\
\text { Like } 90-100 \text { ', but no tuff. }\end{array}$ & Includes prominent $0.5-2.0 \mathrm{~cm}$ graywacke clasts. \\
\hline $\begin{array}{l}120-150(37-46 \\
\mathrm{m})\end{array}$ & Gravel; rounded pebble. & $\begin{array}{l}\text { Clasts include red chert, andesite-rhyodacite, quartzite, } \\
\text { black chert/argillite. }\end{array}$ \\
\hline $\begin{array}{l}150-160(46-49 \\
m)\end{array}$ & Sand; medium to fine grained. & $\begin{array}{l}\text { Includes black rounded "globules" of obsidian glass; } \\
\text { doubly terminated, clear, euhedral quartz, what appear } \\
\text { to be fine rounded white water-transported tephra. } \\
\text { Other detritus include serpentinite + other quartz, } \\
\text { argillite, chert (Franciscan Complex and Great Valley } \\
\text { sequence-derived) detritus and Tertiary volcanic } \\
\text { (andesitic-rhyodacitic) detritus. }\end{array}$ \\
\hline $\begin{array}{l}160-170(49-52 \\
m)\end{array}$ & $\begin{array}{l}\text { Sand; orange-brown stained, silt and } \\
\text { silty. }\end{array}$ & $\begin{array}{l}\text { Includes some minor gray pumice grains, clear euhedral } \\
\text { to rounded quartz and feldspar, also cloudy clastic- } \\
\text { derived rounded quartz }+ \text { argillite }+ \text { serpentinite grains, } \\
\text { and some minor very fine grained black glass globules. }\end{array}$ \\
\hline $\begin{array}{l}170-180(52-55 \\
m)\end{array}$ & $\begin{array}{l}\text { Sand; locally gritty, orange-brown } \\
\text { stained, silty to fine grained. }\end{array}$ & $\begin{array}{l}\text { Includes clear euhedral quartz and feldspar, some very } \\
\text { fine black glassy globules + very fine white clumps of } \\
\text { possible tephra, and other Tertiary volcanics, Franciscan } \\
\text { Complex /Great Valley sequence detritus, as above. }\end{array}$ \\
\hline $\begin{array}{l}180-190(55-58 \\
m)\end{array}$ & Same as $170-180$, orange-brown stained. & $\begin{array}{l}\text { Includes some rounded fine sand }(0.3-0.5 \mathrm{~mm}) \text {, white, } \\
\text { euhedral tephra grains. Clear feldspar and some clear } \\
\text { double-terminated quartz, glass globules if present not } \\
\text { obvious. Some red/black grains of possible welded(?) }\end{array}$ \\
\hline
\end{tabular}




\begin{tabular}{|c|c|c|}
\hline & & tuff. \\
\hline $\begin{array}{l}\text { 190-200 (58-61 } \\
\text { m) }\end{array}$ & Sand; gray, quartz-rich, angular silty. & $\begin{array}{l}\text { Some clear feldspar + quartz; possibly some minor } \\
\text { black glass (obsidian?). Significant Franciscan } \\
\text { Complex/Great Valley sequence component. No } \\
\text { obvious tephra. }\end{array}$ \\
\hline $\begin{array}{l}200-210(61-64 \\
\text { m) }\end{array}$ & Sand; gray silty sand, same $190-200$ '. & $\begin{array}{l}\text { No obvious tephra; includes clear + some minute } \\
\text { rounded brown glass(?) "globules." }\end{array}$ \\
\hline $\begin{array}{l}210-220(64-67 \\
\mathrm{m})\end{array}$ & Silt; gray. & $\begin{array}{l}\text { Appears to have very fine tuffaceous(?) matrix and } \\
\text { minor very fine glassy globules + abundant clear to } \\
\text { milky, subhedral to subrounded feldspar and quartz, } \\
\text { mixed with Mesozoic-derived clastics including schist, } \\
\text { and serpentinite. }\end{array}$ \\
\hline $\begin{array}{l}220-230(67-70 \\
\text { m) }\end{array}$ & Silty sand. & $\begin{array}{l}\text { Mostly quartz-feldspar, angular to subangular grains, } \\
\text { with mafic rock fragments (gabbro-diabase). }\end{array}$ \\
\hline $\begin{array}{l}230-240(70-73 \\
\text { m) }\end{array}$ & $\begin{array}{l}\text { Sand; gritty, medium to coarse grained; } \\
\text { like } 220-230 \text {. }\end{array}$ & $\begin{array}{l}\text { Mostly quartz + feldspar, angular to subangular, with } \\
\text { rounded, grit to small pebble-sized clasts of bull quartz, } \\
\text { veined hard argillite, minor gabro-diabase, granitic } \\
\text { quartz-feldspar, and fine-grained rhyolite-dacite } \\
\text { (Tertiary volcanic?) and possible chromite/picotite. }\end{array}$ \\
\hline $\begin{array}{l}240-250(73-76 \\
\text { m) }\end{array}$ & Same as $230-240$. & \\
\hline $\begin{array}{l}\text { 250-260 (76-79 } \\
\mathrm{m})\end{array}$ & Pebbly grit $(\leq 0.75 \mathrm{~cm})$ & $\begin{array}{l}\text { Rounded, with clasts largely of bull quartz, veined dark } \\
\text { grey black argillite, red chalcedonic, felsite volcanic, } \\
\text { and red Franciscan-type radiolarian chert. }\end{array}$ \\
\hline $\begin{array}{l}260-270 \mathrm{~m} \mathrm{(79-} \\
82 \mathrm{~m})\end{array}$ & Same as $250-260$ '. & $\begin{array}{l}\text { Rounded clasts up to } 1 \mathrm{~cm} \text { dominate; prominent red } \\
\text { chert pebble. }\end{array}$ \\
\hline $\begin{array}{l}270-280(82-85 \\
\text { m) }\end{array}$ & Same as $260-270 '$. & \\
\hline $\begin{array}{l}280-290(85-88 \\
\mathrm{m})\end{array}$ & Pebbly to gritty gravel $(\leq 0.5 \mathrm{~cm})$ & $\begin{array}{l}\text { Well rounded, polished clasts, largely of hard, quartz } \\
\text { veined argillite, bull quartz; mostly of Franciscan } \\
\text { melange derivation. }\end{array}$ \\
\hline $\begin{array}{l}\text { 290-300 (88-91 } \\
\mathrm{m})\end{array}$ & Pebble gravel $(\leq 1 \mathrm{~cm})$ & $\begin{array}{l}\text { Well rounded as in } 280-290 \text { ', largely Mesozoic-derived } \\
\text { clasts, spilite/metabasilt, but also including greywacke, } \\
\text { porphy, diabase, quartz, quartzite, quartz-veined } \\
\text { argillite, and red radiolarian chert. }\end{array}$ \\
\hline $\begin{array}{l}\text { 300-310 (91-94 } \\
\mathrm{m})\end{array}$ & $\begin{array}{l}\text { Pebble gravel }(\leq 1 \mathrm{~cm}) \text {; same as } 290- \\
300^{\prime} \text {. }\end{array}$ & $\begin{array}{l}\text { Same well rounded Mesozoic-derived clasts and some } \\
\text { aggregate clasts of coarse rounded sand/grit cemented } \\
\text { by possible altered fine-grained tuff. }\end{array}$ \\
\hline $\begin{array}{l}310-320(94-98 \\
m)\end{array}$ & $\begin{array}{l}\text { Pebble gravel }(\leq 1 \mathrm{~cm}) \text {; same as } 300- \\
310^{\prime} \text {. }\end{array}$ & $\begin{array}{l}\text { Rounded clasts include hard silica cemented chert, } \\
\text { felsite-clast-gritty sandstone, red radiolarian chert, and } \\
\text { composite lumps of quartzose sand with altered tuff } \\
\text { matrix (observed one definite pumice shard in } \\
\text { matrix/interclast area of one sandstone lump). }\end{array}$ \\
\hline $\begin{array}{l}320-330(98- \\
101 \mathrm{~m})\end{array}$ & $\begin{array}{l}\text { Shell fragments }(\geq 80 \% \pm) \text { with sporadic } \\
\text { pebbles }(\leq 0.5 \mathrm{~cm})\end{array}$ & $\begin{array}{l}\text { Includes sporadic pebbles of bull quartz + a few lumps } \\
\text { of lithic quartz-rich sand. }\end{array}$ \\
\hline $\begin{array}{l}330-340(101- \\
104 \mathrm{~m})\end{array}$ & Shell fragments $\geq 85 \% \pm$. & One or two broken pebble fragments. \\
\hline $\begin{array}{l}340-350(104- \\
107 \mathrm{~m})\end{array}$ & $\begin{array}{l}\text { Mixed thin-shell hash }(\sim 70 \% \pm) \text { with } \\
\text { sand + grit. }\end{array}$ & Secondary pyritic coatings locally on shell material. \\
\hline $\begin{array}{l}350-360(107- \\
110 \mathrm{~m})\end{array}$ & Shell hash $(\sim 60 \%),+$ sand grit. & In sand/grit matrix. \\
\hline $\begin{array}{l}360-370(110- \\
113 \mathrm{~m})\end{array}$ & Shell hash, in silty sandy grit; $\sim 90 \%$. & Silty, sandy matrix. \\
\hline \begin{tabular}{|l}
$370-380(113-$ \\
$116 \mathrm{~m})$ \\
\end{tabular} & $\begin{array}{l}\text { Shell hash in gritty, rounded sandstone- } \\
\text { clast matrix; } \sim 75 \%\end{array}$ & Gritty, rounded, sandstone matrix. \\
\hline 380-390 (116- & Silty-sand with bivalve/gastropod hash. & Foraminifer picked (slide slot \#19). \\
\hline
\end{tabular}




\begin{tabular}{|c|c|c|}
\hline $119 \mathrm{~m})$ & & \\
\hline $\begin{array}{l}390-400(119- \\
122 \mathrm{~m})\end{array}$ & $\begin{array}{l}\text { Pebbly }(\leq 1.3 \mathrm{~cm}) \text { silt with admixed shell } \\
\text { hash. }\end{array}$ & Matrix is silty with pebbles. \\
\hline $\begin{array}{l}400-410(122- \\
125 \mathrm{~m})\end{array}$ & Same as $390-400^{\prime}$ & One possible green glauconite pellet(?) observed. \\
\hline $\begin{array}{l}410-420(125- \\
128 \mathrm{~m})\end{array}$ & Same as $400-410^{\prime}$ & Includes some lumps of what look like altered grey ash. \\
\hline $\begin{array}{l}420-430(128- \\
131 \mathrm{~m})\end{array}$ & $\begin{array}{l}\text { Silty-sand; fine-grained with } \sim 75 \% \text { fossil } \\
\text { shell material. }\end{array}$ & Silty fine-grained-sand matrix. \\
\hline $\begin{array}{l}430-440(131- \\
134 \mathrm{~m})\end{array}$ & $\begin{array}{l}\text { Sand; pebbly }(\leq 0.66 \mathrm{~cm}) \text {, fine-grained, } \\
\text { with shell fragments and minor } \\
\text { fragments of carbonate-cemented, } \\
\text { quartzo-feldspathic clasts. }\end{array}$ & \\
\hline \begin{tabular}{|l}
$440-450(134-$ \\
$137 \mathrm{~m})$ \\
\end{tabular} & $\begin{array}{l}\text { Shell fragments }(\sim 50 \%) \text {, in silty matrix } \\
(\sim 30 \%) \text { and pebbles }(\sim 20 \%) \text {. }\end{array}$ & $\begin{array}{l}\text { Few round cherty veined argillite pebbles }(\leq 1 \mathrm{~cm}) \\
\text { make up } \sim 20 \% \text {. }\end{array}$ \\
\hline $\begin{array}{l}450-460(137- \\
140 \mathrm{~m})\end{array}$ & $\begin{array}{l}\text { Shell hash with silt matrix; } \sim \text { same as } \\
440-450 \text { ', cements. }\end{array}$ & \\
\hline $\begin{array}{l}460-470(140- \\
143 \mathrm{~m})\end{array}$ & - similar to $450-460^{\prime}$ & \\
\hline $\begin{array}{l}470-480(143- \\
146 \mathrm{~m})\end{array}$ & $\begin{array}{l}\text { similar to } 460-470 \text { '; matrix slighly } \\
\text { coarser (i.e., silty fine sand). }\end{array}$ & \\
\hline $\begin{array}{l}480-490(146- \\
149 \mathrm{~m}) \\
\end{array}$ & $\begin{array}{l}\text { Sand; bioclastic, fine to coarse, with } \\
\text { rounded polished grit-sized clasts. }\end{array}$ & Milky quartz prominent grit clast component. \\
\hline $\begin{array}{l}490-500(149- \\
152 \mathrm{~m})\end{array}$ & $\begin{array}{l}\text { Sand; bioclastic }(\sim 50 \%), \text { same as } 480- \\
490 \text { ', with rounded polished grit to small } \\
\text { pebble sized clasts }(\leq 0.5 \mathrm{~cm}) \text {. }\end{array}$ & Pebble and grit clasts include quartz and bull quartz. \\
\hline \begin{tabular}{|l}
$500-510(152-$ \\
$155 \mathrm{~m})$
\end{tabular} & $\begin{array}{l}\text { Sand; bioclastic }(\sim 40 \%) \text {, pebbly to gritty. } \\
\text { Similar to } 490-500^{\prime} \text {. }\end{array}$ & A few rounded green pellet-like (glauconite?) grains. \\
\hline $\begin{array}{l}510-520(155- \\
158 \mathrm{~m}) \\
\end{array}$ & $\begin{array}{l}\text { Sand; bioclastic, pebbly to gritty; same } \\
\text { as 500-510'. }\end{array}$ & \\
\hline \begin{tabular}{|l}
$520-530(158-$ \\
$162 \mathrm{~m})$
\end{tabular} & $\begin{array}{l}\text { Silty fine sand; quartzo-feldspathic with } \\
-20 \% \text { shell fragments. }\end{array}$ & \\
\hline \begin{tabular}{|l}
$530-540(162-$ \\
$165 \mathrm{~m})$
\end{tabular} & Silt to fine sand; same as 520-530'. & $\begin{array}{l}\text { Silt to fine sand with a few scattered polished rounded } \\
\text { grit to } \leq 0.5 \mathrm{~cm} \text { pebbles, including red chert. }\end{array}$ \\
\hline $\begin{array}{l}540-550(165- \\
168 \mathrm{~m})\end{array}$ & $\begin{array}{l}\text { Silty sand; fine to medium grained, } \\
\text { bioclastic,; } \sim \text { same as } 520-530^{\prime} \text {. }\end{array}$ & \\
\hline $\begin{array}{l}550-560(168- \\
171 \mathrm{~m}) \\
\end{array}$ & - same as 540-550'. & \\
\hline \begin{tabular}{|l}
$560-570(171-$ \\
$174 \mathrm{~m})$
\end{tabular} & - same as 550-560'. & \\
\hline \begin{tabular}{|l}
$570-580(174-$ \\
$177 \mathrm{~m})$
\end{tabular} & - same as 560-570'. & $\begin{array}{l}\text { A few clear, euhedral, feldspar grains + altered } \\
\text { yellowish brown composite tuff grains; any glass gone } \\
\text { to clay. }\end{array}$ \\
\hline \begin{tabular}{|l}
$580-590(177-$ \\
$180 \mathrm{~m})$ \\
\end{tabular} & Silty sand; bioclastic; same as $560-570^{\prime}$. & \\
\hline \begin{tabular}{|l}
$590-600(180-$ \\
$183 \mathrm{~m})$ \\
\end{tabular} & Silty sand; cemented bioclastic. & \\
\hline \begin{tabular}{|l}
$600-610(183-$ \\
$186 \mathrm{~m})$ \\
\end{tabular} & Silty bioclastic bed. & Agglutinated foraminifers? \\
\hline $\begin{array}{l}610-620(186- \\
189 \mathrm{~m})\end{array}$ & $\begin{array}{l}\text { Bioclastic bed with minor silt matrix and } \\
\text { a few, } \leq 0.3 \mathrm{~cm} \text {, hard, rounded, milky- } \\
\text { bull quartz, and cherty argillite clasts. }\end{array}$ & \\
\hline $\begin{array}{l}620-630(189- \\
192 \mathrm{~m})\end{array}$ & $\begin{array}{l}\text { Silt; bioclastic with angular quartzo- } \\
\text { feldspathic matrix. }\end{array}$ & $\begin{array}{l}\text { Matrix silt locally with clumps of } \mathrm{CO}_{3} \text { cemented } \\
\text { sandstone and shell. }\end{array}$ \\
\hline $\begin{array}{l}630-640(192- \\
195 \mathrm{~m})\end{array}$ & Silt; with 20\% shell fragments. & $\begin{array}{l}\text { Silty sediment, angular, quartzo-feldspathic, with sand- } \\
\text { sized rounded polished, hard black grains, and milky }\end{array}$ \\
\hline
\end{tabular}




\begin{tabular}{|c|c|c|}
\hline & & bull quartz. \\
\hline $\begin{array}{l}640-650(195- \\
198 \mathrm{~m})\end{array}$ & Silt; with minor ( 15\%) shell fragments. & Silt, possibly has ash component? \\
\hline $\begin{array}{l}650-660(198- \\
201 \mathrm{~m})\end{array}$ & Silt; with slight oxidation to orange-grey. & $\begin{array}{l}\text { Possible ashy component to silt(?) with a few black ( } \leq \\
0.5 \%) \text { scoria-like grains. }\end{array}$ \\
\hline $\begin{array}{l}660-670(201- \\
204 \mathrm{~m})\end{array}$ & Pebbly silt; like 650-660'. & $\begin{array}{l}\text { Possible ashy, pebbly, silt, not as oxidized as above. } \\
\text { Includes rounded quartz } \pm \text { cherty veined argillite } \\
\text { pebbles } \leq 1 \mathrm{~cm} \text { diameter. }\end{array}$ \\
\hline $\begin{array}{l}670-680(204- \\
207 \mathrm{~m})\end{array}$ & $\begin{array}{l}\text { Grit; well sorted (clast supported?) } \\
\text { rounded/polished. }\end{array}$ & $\begin{array}{l}\text { Includes clasts of spilitic metabasalt, hard recrystallized } \\
\text { quartose-meta-sandstone, bull quartz, and cherty veined } \\
\text { argillite. }\end{array}$ \\
\hline $\begin{array}{l}680-690(207- \\
210 \mathrm{~m})\end{array}$ & $\begin{array}{l}\text { "Pea gravel;" well sorted with pebbles } \leq \\
0.6 \mathrm{~cm} \text {; clast supported. }\end{array}$ & $\begin{array}{l}\text { Clasts rounded and polished, including red metachert, } \\
\text { black cherty argillite; same suite as 670-680'. }\end{array}$ \\
\hline $\begin{array}{l}690-700(210- \\
213 \mathrm{~nm}\end{array}$ & - same as 680-690'. & \\
\hline $\begin{array}{l}700-710(213- \\
216 \mathrm{~m})\end{array}$ & - same as 690-700'. & Clasts include metaquartzite and vein quartz. \\
\hline $\begin{array}{l}710-720(216- \\
219 \mathrm{~m})\end{array}$ & $\begin{array}{l}\text { Pebbly-gravel; same as 700-710'; } \\
\text { includes fine silty sand matrix. }\end{array}$ & \\
\hline $\begin{array}{l}720-730(219- \\
223 \mathrm{~m})\end{array}$ & $\begin{array}{l}\text { Pea gravel; pebbly to gritty, rounded, and } \\
\text { polished clasts } \sim 0.25 \text { to } 0.75 \mathrm{~cm} ; \sim \text { same } \\
\text { suite as } 680-690^{\prime} .\end{array}$ & \\
\hline $\begin{array}{l}730-740(223- \\
226 \mathrm{~m})\end{array}$ & $\begin{array}{l}\text { Pea gravel; coarse, rounded, } 0.6-1.0 \mathrm{~cm} \text {, } \\
\text { with minor fine silt as interclast matrix; } \\
\text { otherwise same as } 720-730^{\prime} .\end{array}$ & $\begin{array}{l}\text { Silt locally with pyrite clusters; pebble grit clasts locally } \\
\text { with common } \mathrm{CO}_{3} \text { (calcite?) cement. }\end{array}$ \\
\hline $\begin{array}{l}740-750(226- \\
229 \mathrm{~m})\end{array}$ & Pea gravel; $\sim \leq 1 \mathrm{~cm}$ rounded clasts. & No silt observed, possibly washed out(?). \\
\hline $\begin{array}{l}750-760(229- \\
232 \mathrm{~m})\end{array}$ & $\begin{array}{l}\text { Pea gravel; coarse, rounded, } \sim 0.3-1.2 \\
\text { cm clasts; otherwise } \sim \text { same as } 740-750\end{array}$ & \\
\hline $\begin{array}{l}760-770(232- \\
235 \mathrm{~m})\end{array}$ & $\begin{array}{l}\text { Silty gravel; clasts } \sim 0.3 \text { to } 1.0 \mathrm{~cm}, \text { in } \\
\text { silty matrix (matrix supported?). }\end{array}$ & $\begin{array}{l}\text { Pebble clasts include chert + quartzite and } \sim \text { same clast } \\
\text { suite as } 750-760 \text { '. }\end{array}$ \\
\hline $\begin{array}{l}770-780(235- \\
238 \mathrm{~m})\end{array}$ & $\sim$ same as at $760-770$ & \\
\hline $\begin{array}{l}780-790(238- \\
241 \mathrm{~m})\end{array}$ & Pea gravel; silty. $\sim$ same as 770-780. & \\
\hline $\begin{array}{l}790-800(241- \\
244 \mathrm{~m})\end{array}$ & same as 780-790'. & \\
\hline $\begin{array}{l}800-810(244- \\
247 \mathrm{~m})\end{array}$ & $\begin{array}{l}\text { Sand; silt to fine grained with minor } \\
\text { sporadic rounded pebbles }(0.3-1.0 \mathrm{~cm}) \text {. } \\
\text { Possibly drifted down-hole(?). }\end{array}$ & \\
\hline $\begin{array}{l}810-820(247- \\
250 \mathrm{~m})\end{array}$ & $\begin{array}{l}\text { Sand; bioclastic, silt to fine sand, with } \\
\text { sporadic broken pebbles. }\end{array}$ & $\begin{array}{l}\text { Includes questionable tuff component in fine grained } \\
\text { silt. }\end{array}$ \\
\hline $\begin{array}{l}820-830(250- \\
253 \mathrm{~m})\end{array}$ & $\begin{array}{l}\text { Sand; silty, fine sand, with abundant to } \\
\text { common bioclastics; same as } 810-820 \text {, } \\
\text { but no pebbles and fewer shell } \\
\text { fragments. }\end{array}$ & \\
\hline $\begin{array}{l}\text { 830-840TD } \\
(253-256 \mathrm{~m})\end{array}$ & $\begin{array}{l}\text { Silt; fine sandy silt; same as } 820-830 \text { ', } \\
\text { but with slightly greater silt content and } \\
\text { fewer shell fragments. }\end{array}$ & \\
\hline
\end{tabular}




\section{Lithologic logs of washed ditch samples from Sonoma County Water Agency- Sebastopol Road pilot well located at $38.4085^{\circ} \mathrm{N}, 122.7995^{\circ} \mathrm{W}$ (NAD27), along the Petaluma and Santa Rosa railroad line about midway between Llano and the Sebastopol Grange (just north of Gravenstein), Sebastopol 7.5' Quadrangle, Sonoma County, California.}

\begin{tabular}{|c|c|c|}
\hline Depth (ft) & Lithology & Notes \\
\hline $20-30(6-9 \mathrm{~m})$ & $\begin{array}{l}\text { Clay; with rare subrounded } 0.5 \mathrm{~cm} \\
\text { pebbles, compact, gray. }\end{array}$ & $\begin{array}{l}\text { Non-calcareous; possibly derived from ash/bentonite; } \\
\text { appears to include areas of white chunks of fine grained, } \\
\text { undevitrified, tephra, some with feldspar } \\
\text { microphenocrysts. Includes rare subrounded } 0.5 \mathrm{~cm} \\
\text { pebbles of meta-sandstone and altered mafic rock (silica } \\
\text { carbonate?). }\end{array}$ \\
\hline $30-40(9-12 \mathrm{~m})$ & Pebble-gravel; rounded, $0.5-2.0 \mathrm{~cm}$. & $\begin{array}{l}\text { Multi-lithologic, with abundant clasts of rounded, banded } \\
\text { to non-banded, porphyritic, white rhyolite-dacite, rare red } \\
\text { (baked?) siliceous volcanic clasts (derived from Miocene } \\
\text { andPliocene volcanics rocks), lithic metasandstone } \\
\text { (Franciscan Complex/Great Valley sequence), + minor } \\
\text { chunks of clayey matrix like at 20-30'. }\end{array}$ \\
\hline $40-50(12-15 \mathrm{~m})$ & $\begin{array}{l}\text { Pebble gravel; rounded to subrounded, } \\
\text { like at } 30-40^{\prime} \text {, but coarser }(<2.5 \mathrm{~cm}) \text {, and } \\
\text { with more clayey matrix. }\end{array}$ & $\begin{array}{l}\text { Large subrounded clasts up to } 2.5 \mathrm{~cm} \text { of hard porphyritic, } \\
\text { gray to white rhyolite/rhyodacite (probably from Tertiary } \\
\text { volcanic section). Also includes hard welded rhyodacite, } \\
\text { (also from Tertiary volcanic section - affinity to } \\
\text { Zammaroni-Warrington Road section?); hard, rounded, } \\
\text { medium grained, lithic arkosic wacke; fine grained cherty, } \\
\text { dark grey, argillite; one tan rounded clast of possible } \\
\text { porcellanite (no foraminifers), or fine-grained banded } \\
\text { rhyolite; includes chunks of possibly tuffaceous matrix } \\
\text { clay. Like 20-30' (down hole sluff or in place(?). }\end{array}$ \\
\hline $50-60(15-18 \mathrm{~m})$ & $\begin{array}{l}\text { Clay; brownish gray, compact; similar to } \\
\text { clay at } 20-30 \text { ' but more brown. }\end{array}$ & May be derived from devitrified ash?? \\
\hline 60-70 (18-21 m) & Grit; rounded to subrounded. & $\begin{array}{l}\text { Composed of mixed Mesozoic- igneous rocks, argillite, } \\
\text { and rounded white rhyolite/dacite. }\end{array}$ \\
\hline $70-80(21-34 \mathrm{~m})$ & Grit; rounded $\sim$ same as $60-70^{\prime}$. & Includes rounded white rhyodacite clasts. \\
\hline $80-90(24-27 \mathrm{~m})$ & $\begin{array}{l}\text { Grit; rounded to subangular, otherwise } \\
\text {-same as } 70-80^{\prime} \text {. }\end{array}$ & $\begin{array}{l}\text { Includes much subrounded white rhyodacite clasts + } \\
\text { flaggy rhyolitc (or diatomitic?) shale. }\end{array}$ \\
\hline $\begin{array}{l}90-100(27-30 \\
\mathrm{m})\end{array}$ & Pebbly clay; brownish grey. & $\begin{array}{l}\text { Pebbles }(\sim 1.0 \mathrm{~cm}) \text { of banded chalcedony, veined } \\
\text { rhyodacite, green spilite and milky quartz grit; clay may be } \\
\text { very fine grained (devitrified?) ash. }\end{array}$ \\
\hline $\begin{array}{l}100-110(30-34 \\
m)\end{array}$ & Pebbly clay; $\sim$ same as $90-100^{\prime}$. & $\begin{array}{l}\text { Pebbles }<1.3 \mathrm{~cm} \text {; clay may be fine grained devitrified ash. } \\
\text { Pebbles of rounded, white rhyodacite, hard lithic meta- } \\
\text { sandstone, vein quartz, meta-graywacke, and argillite. }\end{array}$ \\
\hline $\begin{array}{l}110-120(34-37 \\
m)\end{array}$ & Pebbly clay; same as $100-110$ '. & $\begin{array}{l}\text { Subrounded to subangular pebbles up to } \sim 1.2 \mathrm{~cm} \text { include } \\
\text { greenstone, meta-gabbro, quartzite, and argillite; clay } \\
\text { somewhat sandy to gritty, may be ashy, like above(?). } \\
\text { Fine, euhedral, clear feldspar and clear, angular, quartz in } \\
\text { matrix clay. }\end{array}$ \\
\hline $\begin{array}{l}120-130(37-40 \\
\mathrm{m})\end{array}$ & $\begin{array}{l}\text { Pebbly clay; } \sim \text { same as } 110-120 \text { ', but with } \\
\text { only } 1 \text { large pebble } \sim 2.0 \mathrm{~cm} .\end{array}$ & $\begin{array}{l}\text { Pebble subangular, hard, grey, recrystalized felsite } \\
\text { porphyry (probably old, reworked); possibly sluff down- } \\
\text { hole. Clay with locally prominent(?) white, ash "chunk." } \\
\text { Clay matrix with fine, angular to subrounded, aggregates } \\
\text { to single grains of clear, fresh quartz or feldspar? Clay is } \\
\text { probably devitrified fine grained ash, though can't see } \\
\text { shards? }\end{array}$ \\
\hline $\begin{array}{ll}130-140(40-43 \\
\text { m) }\end{array}$ & Pebbly clay; $\sim$ same as at $120-130$ & $\begin{array}{l}\text { Clay appears ashy as above, with clear euhedral -subhedral } \\
\text { quartz-feldspar grains. }\end{array}$ \\
\hline
\end{tabular}




\begin{tabular}{|c|c|c|}
\hline $\begin{array}{l}140-150(43-46 \\
m)\end{array}$ & $\begin{array}{l}\text { Clay; muddy, grey; same unit as } 130- \\
140 \text { ', but no pebbles and very fine silt } \\
\text { component. }\end{array}$ & $\begin{array}{l}\text { Some clay pieces look graded from mud to clay; chunks of } \\
\text { questionable fine-white ash present. }\end{array}$ \\
\hline $\begin{array}{l}150-160(46-49 \\
m)\end{array}$ & $\begin{array}{l}\text { Mud; clayey to silty, same as at } 140- \\
150 \text { '; higher component of silt and fine } \\
\text { sand than above. }\end{array}$ & $\begin{array}{l}\text { Approximate base of clay unit; includes definite higher } \\
\text { component of silt to fine sand than above; observed one } \\
0.5 \mathrm{~cm} \text { round pebble of milky bull quartz in clayey (ashy?) } \\
\text { mud. }\end{array}$ \\
\hline $\begin{array}{l}160-170(49-52 \\
\text { m) }\end{array}$ & $\begin{array}{l}\text { Sand; fine-grained, well-sorted, } \\
\text { dominantly round-subrounded quartz-rich } \\
\text { sand (dune?). }\end{array}$ & $\begin{array}{l}\text { Sand dominantly well sorted, rounded to subrounded; } \\
\text { quartz rich; with bull quartz, black argillite, chert lithics. }\end{array}$ \\
\hline $\begin{array}{l}170-180(52-55 \\
\text { m) }\end{array}$ & - same as $160-170 '$. & \\
\hline $\begin{array}{l}180-190(55-58 \\
\text { m) }\end{array}$ & - same as 170-180'. & \\
\hline $\begin{array}{l}190-200(58-61 \\
m)\end{array}$ & - same as $180-190$. & Base of well sorted unit. \\
\hline $\begin{array}{l}200-210(61-64 \\
m)\end{array}$ & $\begin{array}{l}\text { Silt; same composition as } 190-200 ' \text { ', but } \\
\text { less sorted and with mud component. }\end{array}$ & Distinctly different hydrodynamic unit from above unit. \\
\hline $\begin{array}{l}210-220(64-67 \\
m)\end{array}$ & Silt; same as 200-210'. & $\begin{array}{l}\text { Matrix with clayey component, possibly tuffaceous, but if } \\
\text { so ash is completely altered to clay. }\end{array}$ \\
\hline $\begin{array}{l}220-230(67-70 \\
\mathrm{m})\end{array}$ & $\begin{array}{l}\text { Sand; medium to fine grained, } \\
\text { moderately sorted, rounded to } \\
\text { subrounded, quartz-rich, multimodal. }\end{array}$ & $\begin{array}{l}\text { Multimodal sand, with lithics from Franciscan } \\
\text { Complex/Great Valley sequence/ophiolite sources (black } \\
\text { chert/argillite,serpentinite, greenstone, mafic igneous, bull } \\
\text { quartz, etc.). Euhedral quartz + feldspar relatively clear, } \\
\text { probably from Tertiary volcanics. }\end{array}$ \\
\hline $\begin{array}{l}230-240(70-73 \\
\text { m) }\end{array}$ & - same as at $220-230^{\prime}$. & \\
\hline $\begin{array}{l}240-250(73-76 \\
m)\end{array}$ & $\begin{array}{l}\text { Sand; Poorly sorted, silty to medium- } \\
\text { grained; same unit as at } 230-240 \text { ', but } \\
\text { poorer sorting. }\end{array}$ & $\begin{array}{l}\text { Picotite (or ilmenite?) grains noted in fine-grained } \\
\text { population. }\end{array}$ \\
\hline $\begin{array}{l}250-260(76-79 \\
m)\end{array}$ & $\begin{array}{l}\text { Sandy-silt; greenish orange, probable top } \\
\text { of new sedimentation unit; unsorted, with } \\
\text { weathered, altered clayey matrix } \\
\text { component. }\end{array}$ & Coloration change due to groundwater/fluids? \\
\hline $\begin{array}{l}260-270(79-82 \\
m)\end{array}$ & $\begin{array}{l}\text { Silt; quartz-rich; subangular-subround, } \\
\text { moderately sorted; same as at 250-260'. }\end{array}$ & \\
\hline $\begin{array}{l}270-280(82-85 \\
\text { m) }\end{array}$ & - same as at $260-270$ '. & \\
\hline $\begin{array}{l}280-290(85-88 \\
m)\end{array}$ & $\begin{array}{l}\text { Sand; silty, fine grained, moderately } \\
\text { sorted, subangular-subround; same as } \\
\text { 280-290'. }\end{array}$ & \\
\hline $\begin{array}{l}290-320(88-98 \\
m)\end{array}$ & 280-290'. & \\
\hline $\begin{array}{l}320-330(98- \\
101 \mathrm{~m})\end{array}$ & $\begin{array}{l}\text { Sand; silty fine grained; same as } 290- \\
320 \text { '. }\end{array}$ & \\
\hline $\begin{array}{l}330-340(101- \\
104 \mathrm{~m})\end{array}$ & $\begin{array}{l}\text { Sand; fine grained, moderately well } \\
\text { sorted, subangular-subrounded, quartz- } \\
\text { rich, lithic; 320-330'. }\end{array}$ & (dune or beach?). \\
\hline $\begin{array}{l}340-350(104- \\
107 \mathrm{~m})\end{array}$ & $\begin{array}{l}\text { Sand; fine to medium grain, well sorted; } \\
\text { same as } 330-340 \text { '. }\end{array}$ & Sporadic subhedral grains of clear feldspar. \\
\hline $\begin{array}{l}350-360(107- \\
110 \mathrm{~m})\end{array}$ & $\begin{array}{l}\text { Sand; fine-medium grain, well sorted; } \\
\text {-same as } 340-350 \text { '. }\end{array}$ & No fines (dune sand?). \\
\hline $\begin{array}{l}360-370(110- \\
113 \mathrm{~m})\end{array}$ & $\begin{array}{l}\text { Sand; medium grain, lithic, quartzo- } \\
\text { feldspathic, poorly sorted, subangular. }\end{array}$ & New sedimentation unit? \\
\hline \begin{tabular}{|l|}
$370-380(113-$ \\
$1 ` 16 \mathrm{~m})$
\end{tabular} & $\begin{array}{l}\text { Sand; poorly sorted, lithic, subangular, } \\
\text { medium grained. }\end{array}$ & \\
\hline
\end{tabular}




\begin{tabular}{|c|c|c|}
\hline $\begin{array}{l}380-390(116- \\
119 \mathrm{~m})\end{array}$ & $\begin{array}{l}\text { Sand with grit; lithic, bimodal, with } \\
\text { medium grained, subrounded to } \\
\text { subangular, quartzofeldspathic sand } \\
\text { matrix with rounded grit, } 0.25-0.3 \mathrm{~cm} \text {. }\end{array}$ & Grit clasts include bull quartz and dark veined argillite \\
\hline $\begin{array}{l}390-400(119- \\
122 \mathrm{~m})\end{array}$ & $\begin{array}{l}\text { Sand with grit; } \sim \text { same as } 380-390 \text { ', with } \\
\text { small pebbles, }<0.5 \mathrm{~cm} \text {. }\end{array}$ & \\
\hline $\begin{array}{l}400-410(122- \\
125 \mathrm{~m})\end{array}$ & $\begin{array}{l}\text { Sand with pebbles and grit; fine to coarse } \\
\text { grained, poorly sorted, angular to } \\
\text { subrounded, sand, with sporadic, } \\
\text { rounded, pebbles and grit. }\end{array}$ & $\begin{array}{l}\text { Pebbles and grit Franciscan-derived, with cherty-veined } \\
\text { argillite, bull quartz. }\end{array}$ \\
\hline \begin{tabular}{|l}
$410-420(125-$ \\
$128 \mathrm{~m})$ \\
\end{tabular} & $\begin{array}{l}\text { Sand with pebbles and grit; } \sim \text { same as at } \\
400-410 \text {. }\end{array}$ & \\
\hline $\begin{array}{l}420-430(128- \\
131 \mathrm{~m})\end{array}$ & $\begin{array}{l}\text { Sand with grit to pebbles; medium } \\
\text { grained, moderately sorted, rounded to } \\
\text { angular; same as } 410-420 \text { ', but slightly } \\
\text { coarser. }\end{array}$ & \\
\hline $\begin{array}{l}430-440(131- \\
134 \mathrm{~m})\end{array}$ & $\begin{array}{l}\text { Sand with grit and pebbles; rounded to } \\
\text { subangular, coarse to medium, sand, with } \\
\text { subrounded grit to fine pebble }(<.5 \mathrm{~cm}) \\
\text { clasts; same as } 420-430^{\prime} \text {. }\end{array}$ & \\
\hline $\begin{array}{l}440-450(134- \\
137 \mathrm{~m})\end{array}$ & $\begin{array}{l}\text { Pea-gravel; rounded, sandy, clasts }<0.6 \\
\text { cm); } \sim \text { same as at } 430-440 ', \text { but } \\
\text { significantly more pebbles }(\sim 50 \%) .\end{array}$ & Beach? \\
\hline $\begin{array}{l}450-460(137- \\
140 \mathrm{~m})\end{array}$ & $\begin{array}{l}\text { Pea-gravel; same as } 440-450 \text { ', but } \\
\text { pebbles < } 0.3 \mathrm{~cm} .\end{array}$ & Probable beach. \\
\hline $\begin{array}{l}460-470(140- \\
143 \mathrm{~m})\end{array}$ & Sandy gravel; $\sim$ same as $440-450 '$. & \\
\hline $\begin{array}{l}470-480(143- \\
146 \mathrm{~m})\end{array}$ & $\begin{array}{l}\text { Pea gravel; rounded to subrounded, } \sim 0.5 \\
\text { to } 1 \mathrm{~cm} \text {, with minor fine sand matrix and } \\
\text { minor abraded angular shell fragments. }\end{array}$ & $\begin{array}{l}\text { Clasts include veined argillite, bull quartz, red chert, other } \\
\text { Franciscan-derived clasts. }\end{array}$ \\
\hline $\begin{array}{l}480-490(146- \\
149 \mathrm{~m})\end{array}$ & $\begin{array}{l}\text { Shell fragments; } \sim 80 \% \text { with } \sim 20 \% \text { pea to } \\
\text { grit-sized rounded clasts of same clast } \\
\text { suite as seen in } 470-480^{\prime} \text {. }\end{array}$ & Top of new bioclastic unit \\
\hline $\begin{array}{l}490-500(149- \\
152 \mathrm{~m})\end{array}$ & $\begin{array}{l}\text { Pea gravel; Bioclastic, } \sim 50 \% \text { bivalves and } \\
\text { pebbles, }<1 \mathrm{~cm} ; \sim 50 \% \text { rounded } \sim 0.3-1.0 \\
\mathrm{~cm} \text {. }\end{array}$ & \\
\hline $\begin{array}{l}500-510(152- \\
155 \mathrm{~m})\end{array}$ & $\begin{array}{l}\text { Gravel; sandy, bioclastic, } \sim 50 \% \text { angular } \\
\text { shell fragments, 30\% fine-medium sand; } \\
\text { 20\% rounded pebbles; as in 490-500'. }\end{array}$ & \\
\hline $\begin{array}{l}510-520(155- \\
158 \mathrm{~m})\end{array}$ & $\begin{array}{l}\text { Gravel; same as 500-510'; somewhat } \\
\text { less sand. }\end{array}$ & \\
\hline $\begin{array}{l}520-530(158- \\
162 \mathrm{~m})\end{array}$ & $\begin{array}{l}\text { Sand; bioclastic, fine grained, subrounded } \\
\text { to subangular, shell fragments up to } \sim 0.5 \\
\mathrm{~cm} \text {, with }<1 \% \text { rounded grit to } \sim 0.3 \mathrm{~cm} .\end{array}$ & $\begin{array}{l}\text { Rounded grit to } 0.3 \mathrm{~cm} \text { largely includes black argillite/vein } \\
\text { quartz, (Franciscan Complex/Great Valley sequence- } \\
\text { derived); note pyritic /sulfide coatings on many shell } \\
\text { fragments. }\end{array}$ \\
\hline $\begin{array}{l}530-540(162- \\
165 \mathrm{~m})\end{array}$ & $\begin{array}{l}\text { Sand; bioclastic, same as 520-530', but } \\
\text { somewhat more sand matrix. }\end{array}$ & Some black spherule-shaped $<1 \mathrm{~mm}$-size grains? \\
\hline \begin{tabular}{|l}
$540-550(165-$ \\
$168 \mathrm{~m})$
\end{tabular} & Sand; bioclastic; same as 530-540'. & $\begin{array}{l}\text { Includeds well rounded, } 1 \mathrm{~cm} \text {, chert (green-gray), also } 1 \\
\text { grain of rare black }(\sim .25-.3 \mathrm{~mm}) \text { glass (obsidian?). }\end{array}$ \\
\hline $\begin{array}{l}550-560(158- \\
161 \mathrm{~m})\end{array}$ & $\begin{array}{l}\text { Sand; bioclastic, fine grained, same as at } \\
540-550 \text { ', but sand is coarser and includes } \\
\text { clasts to } \sim 1 \mathrm{~cm} \text { of subrounded, fine } \\
\text { grained, banded chert (with probable } \\
\text { diatoms/foraminifers), resembles } \\
\text { Monterey Formation chert. }\end{array}$ & $\begin{array}{l}\text { Sand matrix is fine grained (silty), coarser than above, } \\
\text { moderately well sorted, quartz-rich, subangular to } \\
\text { subrounded. }\end{array}$ \\
\hline $560-570(171-$ & Sand; abundant granule-sized rounded & \\
\hline
\end{tabular}




\begin{tabular}{|c|c|c|}
\hline $174 \mathrm{~m})$ & $\begin{array}{l}\text { and polished clasts; sandy matrix }<50 \% \text {; } \\
\text { included are uncommon but distinct } \\
\text { banded porcellaneous chert (Monterey } \\
\text { Formation-like) clasts. Base of bioclastic } \\
\text { zone? }\end{array}$ & \\
\hline $\begin{array}{l}570-580(174- \\
177 \mathrm{~m})\end{array}$ & $\begin{array}{l}\text { "Pea gravel"; granule-sized, polished, } \\
\text { well rounded, well sorted, with matrix } \\
\text { largely lacking (winnowed). }\end{array}$ & $\begin{array}{l}\text { Polished, rounded granule clasts include quartzite, bull } \\
\text { quartz, black argillite/chert. }\end{array}$ \\
\hline $\begin{array}{l}580-590(177- \\
180 \mathrm{~m})\end{array}$ & $\begin{array}{l}\text { "Pea gravel"; some fine sand matrix }(< \\
10 \%) \text {; largely clast supported. Base of } \\
\text { same unit as } 570-580 \text {. }\end{array}$ & \\
\hline $\begin{array}{l}590-600(180- \\
183 \mathrm{~m})\end{array}$ & $\begin{array}{l}\text { Granule to grit gravel; without matrix } \\
\text { (winnowed); granules rounded, well } \\
\text { sorted finer grained (3-5mm). }\end{array}$ & $\begin{array}{l}\text { Grains largely dark chert/argillite, bull quartz, quartzite, } \\
\text { derived from Mesozoic source? Good aquifer? }\end{array}$ \\
\hline $\begin{array}{l}600-610(183- \\
186 \mathrm{~m})\end{array}$ & $\begin{array}{l}\text { Granule to grit gravel; but average clast } \\
\text { size somewhat coarser }(\sim 4-6 \mathrm{~mm}), \\
\text { winnowed, matrix lacking, well rounded } \\
\text { and polished. same unit as at } 590-600^{\prime}, \text {. }\end{array}$ & $\begin{array}{l}\text { Same Mesozoic source for clasts as above; probably good } \\
\text { aquifer? }\end{array}$ \\
\hline $\begin{array}{l}610-620(186- \\
189 \mathrm{~m})\end{array}$ & $\begin{array}{l}\text { Granule to grit gravel; same unit as } \\
600-610^{\prime} .\end{array}$ & Well rounded and polished granule gravel. Aquifer? \\
\hline $\begin{array}{l}620-630(189- \\
192 \mathrm{~m})\end{array}$ & $\begin{array}{l}\text { Granule to grit gravel; same as } 610-620 ' \\
\text { Base of unit? }\end{array}$ & $\begin{array}{l}\text { Granule size range } \sim 3-6 \mathrm{~mm} \text {; one angular clast of banded } \\
\text { travertine; either shell fragment or vein material? Aquifer } \\
\text { base? }\end{array}$ \\
\hline $\begin{array}{l}630-640(192- \\
195 \mathrm{~m})\end{array}$ & $\begin{array}{l}\text { Granule to grit; less well sorted than } \\
\text { above, no fines (winnowed), well } \\
\text { rounded and polished grains. Separate } \\
\text { unit? }\end{array}$ & $\begin{array}{l}\text { A few composite grains of cemented coarse sand grit. } \\
\text { Matrix of these composite grains is fine grained and white, } \\
\text { possibly ash? Unit is otherwise like 620-630' }\end{array}$ \\
\hline $\begin{array}{l}\text { 640-650 (195- } \\
198 \mathrm{~m})\end{array}$ & $\begin{array}{l}\text { Pea gravel; with clasts } \sim 4-10 \mathrm{~mm} \text {; } \\
\text { lithologies } \sim \text { same as above. Top of unit. }\end{array}$ & $\begin{array}{l}\text { Includes } 1 \text { clast (rounded) of fine-grained soft, grey } \\
\text { probable ash (picked, in vial) }\end{array}$ \\
\hline $\begin{array}{l}650-670(198- \\
207 \mathrm{~m})\end{array}$ & Pea gravel; same unit as at $640-650^{\prime}$. & \\
\hline $\begin{array}{l}670-680(204- \\
207 \mathrm{~m})\end{array}$ & $\begin{array}{l}\text { Pea gravel; same unit as 650-670', with < } \\
2 \% \text { fine sand matrix (largely clast } \\
\text { supported), and same subrounded quartz- } \\
\text { veined, red radiolarian chert. }\end{array}$ & \\
\hline $\begin{array}{l}680-690(207- \\
210 \mathrm{~m})\end{array}$ & Pea gravel; same unit as 670-680'. & \\
\hline $\begin{array}{l}690-700(210- \\
213 \mathrm{~m})\end{array}$ & $\begin{array}{l}\text { Sand/silt with granule to pebble-size } \\
\text { clasts, same lithology as } 680-690 \text { '; with } \\
\text { 20-30\% unsorted fine grained sand/silt } \\
\text { matrix. Rounded, polished } \sim 3-12 \mathrm{~mm} \\
\text { granules to pebbles. New unit? }\end{array}$ & $\begin{array}{l}\text { Clasts derived from Franciscan Complex/Great Valley } \\
\text { sequence/Mesozoic sources. }\end{array}$ \\
\hline $\begin{array}{l}700-710(213- \\
216 \mathrm{~m})\end{array}$ & $\begin{array}{l}\text { Silt/sand with granule to pebble size } \\
\text { clasts; same as } 690-700^{\prime}\end{array}$ & \\
\hline $\begin{array}{l}710-720(216- \\
219 \mathrm{~m})\end{array}$ & $\begin{array}{l}\text { Pebbly gravel; polished clasts to } \sim 3-11 \\
\text { mm, with less silty sand than in } 700-710 \text { '. } \\
\text { Base of unit? }\end{array}$ & \\
\hline $\begin{array}{l}720-730(219- \\
223 \mathrm{~m})\end{array}$ & $\begin{array}{l}\text { Gravel; silty (matrix supported), rounded; } \\
\text { includes subangular to subrounded, hard, } \\
\text { banded fine-grained welded tuff and (or) } \\
\text { porcellaneous (diatomaceous?) } \\
\text { mudstones (Monterey Formation?) + } \\
\text { some fine grained tephra-like aggregates } \\
\text { with fresh, clear feldspars and quartz. }\end{array}$ & $\begin{array}{l}\text { Fine grained tephra like aggregates with clear fresh } \\
\text { euhedral feldspar and quartz. }\end{array}$ \\
\hline $\begin{array}{l}730-740(223- \\
226 \mathrm{~m})\end{array}$ & $\begin{array}{l}\text { Pebble gravel; rounded, polished, silty } \\
\text { pebble from } 0.8-1.0 \mathrm{~cm} \text {, with matrix of }\end{array}$ & Pebbles of black chert, argillite, and bull quartz. \\
\hline
\end{tabular}




\begin{tabular}{|c|c|c|}
\hline & $\begin{array}{l}\text { angular to subangular, fine silt and sand, } \\
\text { and clear equant, euhedral feldspar and } \\
\text { quartz grains. Same unit as at } 720-730 \text { '. }\end{array}$ & \\
\hline $\begin{array}{l}740-750(226- \\
229 \mathrm{~m})\end{array}$ & Pebble gravel; same as $730-740$ '. & $\begin{array}{l}\text { includes angular fine, euhedral, clear quartz, feldspar sand } \\
\text { with possible fine tephra? Component }\end{array}$ \\
\hline $\begin{array}{l}750-760(229- \\
232 \mathrm{~m})\end{array}$ & $\begin{array}{l}\text { Silty gravel; same as at } 740-750 \text { ', but } \\
\text { probably more silty ( } 20 \% \text { silt matrix of } \\
\text { subrounded to angular, quartzo- } \\
\text { feldspathic, fine sand). }\end{array}$ & $\begin{array}{l}\text { Pebble and granule clasts include rounded bull quartz, } \\
\text { hard aphanitic rhyolite, porcellanite (Monterey Formation } \\
\text { or freshwater diatomite?). }\end{array}$ \\
\hline $\begin{array}{l}760-770(232- \\
235 \mathrm{~m})\end{array}$ & $\begin{array}{l}\text { Silty granule-pebble gravel; more silty } \\
\text { than at } 750-760 \text { '; definite bimodality. } \\
\text { Pebbles/granules } \sim 0.5-1.0 \mathrm{~cm} \text {; well } \\
\text { rounded, polished. Base of unit. }\end{array}$ & $\begin{array}{l}\text { Pebbles and granules include prominent black argillite, } \\
\text { chert. }\end{array}$ \\
\hline $\begin{array}{l}770-780(235- \\
238 \mathrm{~m})\end{array}$ & Pebbly silt; clast suite same as above unit & $\begin{array}{l}\text { Clast suite includes milky vein quartz, banded } \\
\text { porcellanite/chert (Monterey Formation-like); silt matrix } \\
\text { with much fine, clear, quartz and feldspar, commonly } \\
\text { subhedral to euhedral and equant. }\end{array}$ \\
\hline $\begin{array}{l}780-790(238- \\
241 \mathrm{~m})\end{array}$ & $\begin{array}{l}\text { Pebbly silt and silty mudstone; same as a } \\
770-780 \text { ', but more silt and mud and } \\
\text { clasts to } 1 \mathrm{~cm} \text { as above. }\end{array}$ & $\begin{array}{l}\text { Clasts include some angular fragments (disrupted thin } \\
\text { fissile layer?) of thin-bedded fissile diatomite. }\end{array}$ \\
\hline $\begin{array}{l}790-800(241- \\
244 \mathrm{~m})\end{array}$ & $\begin{array}{l}\text { Pebbly silt; same as at 780-790'. Base of } \\
\text { unit. }\end{array}$ & $\begin{array}{l}\text { Silt includes clear, equant subangular euhedral feldspar. } \\
\text { Pebbles include prominent banded porcellanite/chert } \\
\text { (Monterey Formation-like). }\end{array}$ \\
\hline $\begin{array}{l}800-810(244- \\
247 \mathrm{~m})\end{array}$ & $\begin{array}{l}\text { Granule sand; poorly sorted to unsorted } \\
\text { bioclastic, with fine silty to muddy } \\
\text { matrix. }\end{array}$ & $\begin{array}{l}\text { Granules include Monterey Formation-like buff banded } \\
\text { porcellanite, Franciscan-derived fine-grained schist, bull } \\
\text { quartz, serpentinite. }\end{array}$ \\
\hline $\begin{array}{l}810-820(247- \\
250 \mathrm{~m})\end{array}$ & $\begin{array}{l}\text { Granule sand; poorly sorted, silty, same } \\
\text { as } 800-810^{\prime} \text {. }\end{array}$ & Same clast suite as above \\
\hline $\begin{array}{l}820-830(250- \\
253 \mathrm{~m})\end{array}$ & $\begin{array}{l}\text { Gritty silt and fine sand, with } \sim 1-2 \% \text { shel } \\
\text { fragments; grit sized sand clasts are } \\
\text { rounded to subrounded, and polished. } \\
\text { Silt and fine sand is angular to } \\
\text { subrounded, with common clear quartz } \\
\text { and feldspar. }\end{array}$ & Unit probably is nearshore marine. \\
\hline $\begin{array}{l}830-840(253- \\
256 \mathrm{~m})\end{array}$ & $\begin{array}{l}\text { Gritty silt and fine sand, with }<1 \% \text { shell } \\
\text { fragments; granule/grit sized clasts. Same } \\
\text { as } 820-830^{\prime}\end{array}$ & $\begin{array}{l}\text { Granule/grit sized sediment clasts largely Mesozoic } \\
\text { derived + gray andesite/dacite porphyry (Tertiary), that are } \\
\text { generally rounded but not highly polished. }\end{array}$ \\
\hline $\begin{array}{l}840-850(256- \\
259 \mathrm{~m})\end{array}$ & $\begin{array}{l}\text { Gritty silt and fine sand, with }<1 \% \text { shell } \\
\text { fragments; fine silt matrix with } \\
\text { questionable ash component. Same as } \\
830-840 \text { '. }\end{array}$ & \\
\hline $\begin{array}{l}850-860(259- \\
262 \mathrm{~m})\end{array}$ & $\begin{array}{l}\text { Gritty silt and fine sand, with }<1 \% \text { shell } \\
\text { fragments. Same as at } 840-850 \text {. }\end{array}$ & Rounded andesitic/dacitic granule clasts common. \\
\hline $\begin{array}{l}860-870(262- \\
265 \mathrm{~m})\end{array}$ & $\begin{array}{l}\text { Gritty silt and fine sand, with }<1 \% \text { shell } \\
\text { fragments; with some chips of muddy } \\
\text { siltstone up to } \sim 1 \mathrm{~cm} \text {. Granules, largely } \\
\text { of rounded hard dark argillite; black } \\
\text { chert, are up to } \sim 4 \text { mm diameter. Same } \\
\text { as } 850-860^{\prime} \text {. }\end{array}$ & $\begin{array}{l}\text { Unit probably marine shelf or estuarine, based on shell } \\
\text { fragments and texture. }\end{array}$ \\
\hline $\begin{array}{l}870-880(265- \\
268 \mathrm{~m})\end{array}$ & $\begin{array}{l}\text { Gritty silt and fine sand, with }<1 \% \text { shell } \\
\text { fragments; with an } \sim 1 \mathrm{~cm} \text { diameter } \\
\text { subrounded clast of banded dolomitic } \\
\text { sandstone. Same as at } 860-870 \text {. }\end{array}$ & \\
\hline $\begin{array}{l}880-890(268- \\
271 \mathrm{~m})\end{array}$ & $\begin{array}{l}\text { Gritty silt and fine sand; but with 5-10\% } \\
\text { bioclastic angular, abraded and } \\
\text { concentrated shell fragments; top of new }\end{array}$ & $\begin{array}{l}\text { Well rounded bull quartz, black chert/argillite clasts }<5 \\
\text { mm; and fine-medium-grained angular to subangular } \\
\text { quartz-feldspar sand matrix; estuarine or shelf? }\end{array}$ \\
\hline
\end{tabular}




\begin{tabular}{|c|c|c|}
\hline & unit. Same as at $870-880$. & \\
\hline $\begin{array}{l}890-900(271- \\
274 \mathrm{~m})\end{array}$ & $\begin{array}{l}\text { Gritty silt and fine sand; base of } \\
\text { concentrated bioclastics. Same as at } 880 \text { - } \\
890^{\prime} \text {. }\end{array}$ & \\
\hline $\begin{array}{l}900-910(274- \\
277 \mathrm{~m})\end{array}$ & $\begin{array}{l}\text { Granule-grit-rich silty fine sand; } \\
\text { unsorted, with rare }(<0.5 \%) \text { abraded } \\
\text { shell material. }\end{array}$ & $\begin{array}{l}\text { Local clots of fine silt and sand with questionable ashy? } \\
\text { cement. }\end{array}$ \\
\hline $\begin{array}{l}910-920(277- \\
280 \mathrm{~m})\end{array}$ & $\begin{array}{l}\text { Granule-grit-rich silty fine sand; with } \\
\text { clots/aggregates of fine silty sand; base of } \\
\text { unit. Same as at 900-910'. }\end{array}$ & $\begin{array}{l}\text { Aggregates of fine silty sand with white ashy cementing or } \\
\text { intergranular material? }\end{array}$ \\
\hline $\begin{array}{l}920-930(280- \\
283 \mathrm{~m})\end{array}$ & $\begin{array}{l}\text { Sand; fine grained, moderately sorted } \\
\text { quartzo-feldspathic subangular to } \\
\text { subrounded. }\end{array}$ & Probably marine? \\
\hline $\begin{array}{l}930-940(283- \\
287 \mathrm{~m})\end{array}$ & $\begin{array}{l}\text { Sand; but with rare, grit-sized, rounded } \\
\text { black chert/argillite. Same as at 920-930' }\end{array}$ & \\
\hline $\begin{array}{l}940-950(287- \\
290 \mathrm{~m})\end{array}$ & $\begin{array}{l}\text { Sand; with rare, rounded to subrounded, } \\
\text { white pordcellanite grains (Monterey } \\
\text { Formation-like). Same as at 930-940'. }\end{array}$ & \\
\hline $\begin{array}{l}950-960(290- \\
293 \mathrm{~m})\end{array}$ & Sand; same as 940-950'. & \\
\hline $\begin{array}{l}960-970(293- \\
296 \mathrm{~m})\end{array}$ & $\begin{array}{l}\text { Sand; with sporadic }(<2 \%) \text { granule and } \\
\text { grit-sized subrounded to round grains. } \\
\text { Also includes sporadic "chunks" }(<0.7 \\
\text { cm) of mud with probable tephra } \\
\text { component. Same as } 950-960 \text { '. }\end{array}$ & \\
\hline $\begin{array}{l}970-980(296- \\
299 \mathrm{~m})\end{array}$ & Sand; same as at $960-970$. & \\
\hline $\begin{array}{l}980-990(299- \\
302 \mathrm{~m})\end{array}$ & $\begin{array}{l}\text { Sand; but includes } 1.5 \mathrm{~cm} \text { long hard } \\
\text { Franciscan-like meta-graywacke clast } \\
\text { fragment; common fine "clumps" of } \\
\text { ashy(?) cemented fine sand/silt. Includes } \\
\text { rare angular fragments of light brown } \\
\text { porcellanite with probable planktic } \\
\text { foraminifers. Same as at 970-980'. }\end{array}$ & \\
\hline $\begin{array}{l}990-1000(302- \\
305 \mathrm{~m})\end{array}$ & $\begin{array}{l}\text { Sand; except includes large pebble } \\
\text { fragments }(>1.2-2.0 \mathrm{~cm}) \text { of rounded, } \\
\text { dark gray, dacite porphyry, and the same } \\
\text { clumps of ashy, grey, cemented sand/silt; } \\
\text { also includes thin fragments of silicified } \\
\text { wood with cellular texture (i.e., palm- } \\
\text { like?) or possibly same as foraminiferal } \\
\text { porcellanite fragments as at } 980-990 '(?) \text {. } \\
\text { Same as } 980-990^{\prime} \text {. }\end{array}$ & \\
\hline $\begin{array}{l}1000-1010 \\
(305-308 \mathrm{~m})\end{array}$ & $\begin{array}{l}\text { Sand; with large pebble fragments, large } \\
\text { angular fragments of very fine-grained } \\
\text { ashy silty sand, and fragments of } \\
\text { silicified petrified wood } 2-3 \mathrm{~cm} \text { in length. } \\
\text { Same as at } 990-1000^{\prime} \text {. }\end{array}$ & $\begin{array}{l}\text { Angular pebble fragments include porpyritic, white to } \\
\text { grey, rhyolite (Tertiary source?), and angular fragments of } \\
\text { very fine-grained, ashy(?), silty sand }\end{array}$ \\
\hline $\begin{array}{l}1010-1020 \\
(308-311 \mathrm{~m})\end{array}$ & $\begin{array}{l}\text { Sand; with prominent angular chunks of } \\
\text { vitric, dacite porphyry (probably } \\
\text { Tertiary), and a rounded piece of a bull } \\
\text { quartz pebble }(\sim 8 \mathrm{~mm}) \text {; sililcified wood } \\
\text { fragments largely absent. same unit as } \\
\text { 1000-1010'. }\end{array}$ & \\
\hline $\begin{array}{l}1020-1030 \\
(311-314 \mathrm{~m})\end{array}$ & $\begin{array}{l}\text { Granule-silt; unsorted, with subangular to } \\
\text { angular quartzo-feldspathic-rich matrix. }\end{array}$ & $\begin{array}{l}\text { Quartz-feldspar includes much relatively "fresh"-looking } \\
\text { grains (i.e., first-cycle, probably from siliceous volcanic }\end{array}$ \\
\hline
\end{tabular}




\begin{tabular}{|c|c|c|}
\hline & & $\begin{array}{l}\text { source); granule-size }(<5 \mathrm{~mm}) \text { clasts of round to } \\
\text { subrounded bull quartz, dark chert and argillite derived } \\
\text { from Franciscan Complex/Great Valley sequence/ophiolite } \\
\text { sources; and fragments of white rhyodacitic rock in silt to } \\
\text { fine sand range. }\end{array}$ \\
\hline $\begin{array}{l}1030-1040 \\
(314-317 \mathrm{~m})\end{array}$ & $\begin{array}{l}\text { Pebbly granule-silt; with rounded - } \\
\text { subrounded pebble/granule clasts up to } \\
0.7 \mathrm{~cm} \text {. Approximate base of unit. } \\
\text { Same as } 1020-1030 \text { '. }\end{array}$ & \\
\hline $\begin{array}{l}1040-1050 \\
(317-320 \mathrm{~m})\end{array}$ & $\begin{array}{l}\text { Pebbly to granule-bearing mud; similar to } \\
\text { above unit, but dominantly mud matrix. }\end{array}$ & $\begin{array}{l}\text { Mud may be ashy or bentonitic(?). Includes rounded } \\
\text { pebble of quartzite and some white aggregates/clumps of } \\
\text { coarser, probable siliceous ash/tuff. }\end{array}$ \\
\hline $\begin{array}{l}1050-1060 \\
(320-323 \mathrm{~m})\end{array}$ & $\begin{array}{l}\text { Mud; with rounded granules of same } \\
\text { lithologies as above. }\end{array}$ & \\
\hline $\begin{array}{l}1060-1070 \mathrm{TD} \\
(323-326 \mathrm{~m})\end{array}$ & Bentonitic?/ashy? mud; same as above. & Estuarine? \\
\hline
\end{tabular}

